\title{
A comparison of blood gases, biochemistry, and hematology to ecomorphology in a health assessment of pinfish (Lagodon rhomboides)
}

\author{
Sara Collins ${ }^{1}$, Alex Dornburg ${ }^{2}$, Joseph M Flores ${ }^{2}$, Daniel S Dombrowski ${ }^{3}$, Gregory A Lewbart ${ }^{\text {Corresp. } 4}$ \\ ${ }^{1}$ College of Veterinary Medicine, University of Georgia, Athens, Georgia, United States \\ 2 Research and Collections, North Carolina Museum of Natural Sciences, Raleigh, North Carolina, United States \\ 3 Veterinary Services Unit, North Carolina Museum of Natural Sciences, Raleigh, North Carolina, United States \\ 4 Clinical Sciences, North Carolina State University College of Veterinary Medicine, Raleigh, North Carolina, United States \\ Corresponding Author: Gregory A Lewbart \\ Email address: greg_lewbart@ncsu.edu
}

Despite the promise of hematological parameters and blood chemistry in monitoring the health of marine fishes, baseline data is often lacking for small fishes that comprise central roles in marine food webs. This study establishes blood chemistry and hematological baseline parameters for the pinfish Lagodon rhomboides, a small marine teleost is among the most dominant members of near-shore estuarine communities of the Atlantic Ocean and Gulf of Mexico. Given their prominence, pinfishes are an ideal candidate species to use as a model for monitoring changes across a wide range of near-shore marine communities. However, pinfishes exhibit substantial morphological differences associated with a preference for feeding in primarily sea-grass or sand dominated habitats, suggesting that differences in the foraging ecology of individuals could confound health assessments. Here we collect both baseline data on the blood physiology of pinfish while assessing the relationship between blood parameters and measured aspects of feeding morphology using data collected from 37 individual fishes. Our findings provide new baseline health data for this important near shore fish species and find no evidence for a strong linkage between blood physiology and either sex or measured aspects of feeding morphology. Comparing our hematological and biochemical data to published results from other marine teleost species suggests that analyses of trends in blood value variation correlated with major evolutionary transitions in ecology will shed new light on the physiological changes that underlie the successful diversification of fishes. 
${ }^{1}$ University of Georgia College of Veterinary Medicine, Athens, Georgia

${ }^{2}$ North Carolina Museum of Natural Sciences, Raleigh, North Carolina 27601

9

${ }^{3}$ Department of Clinical Sciences, College of Veterinary Medicine, North Carolina State University, Raleigh, NC

$10 \quad 27607$

11

12

$13 *$ *uthor for correspondence

141060 William Moore Drive

15 Raleigh, NC 27607

16 email: greg_lewbart@ncsu.edu

17 phone: $919-513-6439$

18 fax: 919-513-6464

26 Keywords: Sparidae, geometric morphometrics, feeding ecology, hematology, plasma biochemistry

27 Running Head: Blood and morphology values of pinfish 


\section{Abstract}

29 Despite the promise of hematological parameters and blood chemistry in monitoring the health

30 of marine fishes, baseline data is often lacking for small fishes that comprise central roles in

31 marine food webs. This study establishes blood chemistry and hematological baseline parameters

32 for the pinfish Lagodon rhomboides, a small marine teleost is among the most dominant

33 members of near-shore estuarine communities of the Atlantic Ocean and Gulf of Mexico. Given

34 their prominence, pinfishes are an ideal candidate species to use as a model for monitoring

35 changes across a wide range of near-shore marine communities. However, pinfishes exhibit

36 substantial morphological differences associated with a preference for feeding in primarily sea-

37 grass or sand dominated habitats, suggesting that differences in the foraging ecology of

38 individuals could confound health assessments. Here we collect both baseline data on the blood

39 physiology of pinfish while assessing the relationship between blood parameters and measured

40 aspects of feeding morphology using data collected from 37 individual fishes. Our findings

41 provide new baseline health data for this important near shore fish species and find no evidence

42 for a strong linkage between blood physiology and either sex or measured aspects of feeding

43 morphology. Comparing our hematological and biochemical data to published results from other

44 marine teleost species suggests that analyses of trends in blood value variation correlated with

45 major evolutionary transitions in ecology will shed new light on the physiological changes that

46 underlie the successful diversification of fishes.

47

48

49

50

51 


\section{Introduction}

53

Blood chemistry and hematological parameters have become an increasingly important component of monitoring the health of wild populations (Brenner et al. 2002; Anderson et al. 2010; Lewbart et al. 2014). Blood based health assessments are ideally suited for marine environments, where safety limitations in scientific diving (Dardeau and McDonald 2007) and differences in the efficiency of survey methods across taxa (Willis et al. 2000), have stymied the ability to monitor changes in the physiological health of difficult to observe organisms. With current or potential future changes in marine species population dynamics increasingly linked to a host of contemporary threats including acidification (Orr et al. 2005; Hoegh-Guldberg et al. 2007; Fabry et al. 2008), warming (Stachowicz et al. 2002; Schiel et al. 2004; Near et al. 2012a), or invasion of non native species (Thatje et al. 2005; Albins and Hixon 2013), the ability to rapidly survey physiological changes in a minimally invasive manner holds promise for marine conservation efforts. In particular, collecting data on species that form critical links in marine food webs provides the baseline infrastructure for assessing, or forecasting, changes in the wake of environmental disaster, unexplained morbidity/mortality events, or disease outbreaks (Seaward 1994; Lohner et al. 2001; Harvell et al. 2002).

In the Western Atlantic, pinfish (L. rhomboides) are among the most dominant members of near-shore estuarine communities (Reid Jr 1954; Hansen 1969; Stoner 1980), and are ubiquitous across a variety of habitats from New England to Florida as well as the northern Gulf of Mexico to the Yucatan Peninsula (Orth and Heck 1980; Stoner and Livingston 1984; BonillaGómez et al. 2011). With seasonal abundances capable of altering the composition of estuarine epifaunal seagrass communities (Stoner 1982), these fish form the prey base for many larger fishes at higher trophic levels (Schmidt 1986; Bethea et al. 2006). This abundance has made 
75 pinfish a popular live bait used by recreational and commercial fisherman (Muncy 1984; Adams 76 et al. 1998) with high market demands driving the development of these fish as a potential new 77 aquaculture species (DiMaggio et al. 2010; Ohs et al. 2010; DiMaggio et al. 2013). Given their

78 increasing economic importance, central role in near-shore marine food webs, and high

79 abundances, pinfish are ideal candidates for a comprehensive and minimally invasive health 80 assessments from which to monitor changes in marine communities.

81 Although pinfish exhibit many of the hallmarks of a model species, there is also evidence

82 for substantial differences in morphology and feeding ecology of these fishes at fine-spatial 83 scales (Ruehl et al. 2011). In particular, preferential colonization and settlement in sandy versus 84 eel-grass habitats have been suggested to be a primary axis of selection in pinfish, driving 85 pronounced changes in jaw morphology between geographically proximate sites (Ruehl et al. 86 2011). These changes in jaw morphology occur across all size classes and reflect shifts in diet

87 between seagrass and open sand-flat communities (Luczkovich 1988; Levin et al. 1997; Ruehl et 88 al. 2011). Since changes in feeding ecology have been demonstrated to affect blood parameters in other species such as seals (Thompson et al. 1997), this makes accounting for habitat 90 specificity a potentially necessary step towards developing baseline health models for this 91 species in any site comprised of heterogeneous habitat types.

92 Here we conducted a health assessment of pinfishes, measuring blood gas, biochemistry, 93 and hematology values in an area composed of a mixture of sandy and eel grass habitats from 37 94 individual fishes. Our results were consistent with known blood parameters while greatly 95 expanding upon measured hematological and biochemical data on the species. We further 96 integrated our blood analyses with a combination of linear and geometric morphometric analyses 97 to test for possible relationships between ecomorphology and blood physiology. To the best of 
98 our knowledge, our study is the first to test for potential correlations between ecomorphology

99 and blood physiology within a species of marine fish and provides a new perspective on baseline

100 data for this ecologically important species.

101

\section{Materials and Methods}

103 Ethics Statement

104 This study was conducted at the North Carolina State University Center for Marine Sciences and

105 Technology (CMAST) in Morehead City, North Carolina and approved by the IACUC ethics and

106 animal handling protocol. All handling and sampling procedures were consistent with standard

107 vertebrate protocols and veterinary practices.

108

109

Pinfish Capture

110 Pinfish were captured in Bogue Sound $\left(34.721734^{\circ} \mathrm{N},-76.759587^{\circ} \mathrm{W}\right)$ via lightweight angling

111 gear. We aimed to capture 40 individual fish from this population for baseline estimates. This

112 sampling strategy balanced budget constraints with our ability to capture the variance of

113 quantified parameters and is similar to other health assessments of wild fish (Fazio et al. 2013).

114 Thirty-seven fish were successfully landed with fight times lasting an average of less than 15

115 seconds. Once captured, the fish were placed in a 20L plastic bucket with freshly aerated

116 seawater from the collection site. The fish were immediately transported to the laboratory

117 adjacent to our sampling site, with a transport time of less than 3 minutes. Once in the laboratory,

118 fish were maintained in aerated seawater from the sample site in individual 20L buckets until

119 they were sedated with MS-222. Pinfish were left to acclimatize for 5 minutes after transport and 120 before induction. 
Blood Sample Collection and Handling

123 All fish were sedated with buffered MS-222 (100mg/L) and blood samples were collected

124 intravenously from the coccygeal hemal arch into pre-coated, heparinized U-100 insulin syringes

125 with BD Ultra-Fine ${ }^{\mathrm{TM}}$ needles in the $1 / 2 \mathrm{~mL}$ (50 unit) size. An average of $0.23 \mathrm{~mL}$ was obtained

126 from each fish (standard deviation $=0.05 \mathrm{~mL}$, median $=0.22 \mathrm{~mL}$; see supplemental data). The

127 blood was then loaded into the CG-8+ iSTAT cartridges (Abaxis Corporation, Union City,

128 California, USA) and lactate analyzer (Nova Biomedical Corporation, Waltham, Massachusetts,

129 USA) within 5 minutes of sample collection. As the CG-8+ iSTAT cartridges do not measure

130 lactate, a lactate analyzer (Nova Biomedical Corporation, Waltham, Massachusetts, USA) was

131 additionally used to measure lactate. All blood values were obtained within 5 minutes of sample 132 collection.

Blood Gas and Biochemistry Parameters

135 The biochemistry, blood gas, and electrolyte results were obtained using an iSTAT Portable

136 Clinical Analyzer with CG8+ cartridges. The iSTAT is a portable, handheld, battery-operated

137 electronic device with the ability to measure a wide variety of chemistry, blood gas, and basic

138 hematology parameters with only a few drops $(0.095 \mathrm{~mL})$ of whole, non-coagulated blood. The

139 following parameters were measured and recorded: $\mathrm{pH}$, lactate, $\mathrm{pO} 2, \mathrm{pCO} 2, \mathrm{HCO} 32, \mathrm{Hct}, \mathrm{Hb}$,

$140 \mathrm{Na}, \mathrm{K}, \mathrm{iCa}$, and glucose. The iSTAT device analyzed the blood at $37^{\circ} \mathrm{C}$. Using the equations

141 provided by Mandelman and Skomal (2009), we manually calculated an independent set of

142 corrections for $\mathrm{pH}$ based on the water temperature $(\mathrm{T})$ at the time of sampling $\left(27^{\circ} \mathrm{C}\right)$ : 


$$
p H_{T C}=p H_{M}-0.011(T-37)
$$

143 Corrections for calcium were additionally made using the following equation from Mandelman 144 and Skomal (2009):

$$
i C a_{T C}=i C a_{M}\left(1+-0.53\left[p H_{T C}-p H_{M}\right]\right)
$$

145 For equations 1 and 2, values measured from the iSTAT are denoted by an "M" subscript. Those

146 that were manually temperature corrected by using the equations below are denoted by "TC"

147 subscript. Following the guidelines by Friedrichs et al. (2012), reference intervals were

148 computed using the robust method in the referenceInterval package in R, as Shapiro-Wilks tests

149 (Shapiro and Wilk 1965) suggested blood values to not follow the expectations of a Gaussian

150 distribution. This distribution-independent method of calculating a reference interval is preferred

151 for studies of wild populations with low samples sizes (Friedrichs et al. 2012). Prior to reference

152 interval calculation, outliers were identified and removed using the method of Horn et al. (2001).

153 Confidence intervals of the upper and lower bounds of the reference intervals were calculated

154 using 5000 bootstrap replicates.

Hematology

157 Hematocrit was determined using high-speed centrifugation of blood-filled hematocrit tubes with

158 a Zipocrit Hematocrit Centrifuge (ThermoFisher Scientific, Philadelphia, PA). All white blood

159 cell (WBC) count estimates were performed by the same technician, at a location on the slide

160 where the cells were one layer thick, adjacent to one another (membranes touching), evenly

161 distributed, and showed no signs of morphological changes (Newman et al. 1997). White blood 
162 cell estimates were made by using a $100 \mathrm{X}$ objective lens with immersion oil, counting the

163 number of white blood cells in 10 fields, calculating the average, and then multiplying the

164 number of cells by 2,000 (Consolidated Veterinary Diagnostics 1995; Gaunt et al. 1995). Using a

$165100 \mathrm{X}$ objective lens with immersion oil, differential white blood cell counts were performed by

166 examining 100 white blood cells on a peripheral smear stained with Wright-Giemsa stain and

167 counting the number of lymphocytes, neutrophils, monocytes, and eosinophils (Figure 1). The

168 absolute cell count for each type of cell was calculated by multiplying the percentage of the type

169 of cell by the overall WBC estimate (Newman et al. 1997).

170

171 Specimen Digitization and Dissection

172 Following blood collection, fish were euthanized using an additional dose of MS-222, at

173 a concentration of $>250 \mathrm{mg} / \mathrm{L}$. The fish were left in this solution for at least 10 minutes following

174 cessation of opercular movement. Following euthanasia all specimens were photographed facing

175 left, using a 12 megapixel camera. For each specimen two sets of photographs were taken.

176 Specimens were first photographed with their mouths closed, followed by a second round of

177 photographs taken with mouths opened to their maximum level of jaw protrusion. Following

178 digitization, specimens were dissected and reproductive organs were examined to accurately

179 assign sex to each individual to test for the potential of sexual dimorphism in trait data. All

180 specimens were subsequently deposited in the Ichthyological Collection of the North Carolina

181 Museum of Natural Sciences (NCSM 81424).

182

183 Quantifying Body Shape 
morphometric methods (Bookstein 1997; Adams et al. 2004; Zelditch et al. 2012) in the TpsDIG2 software package (Rohlf 2005). To quantify body shape, 27 homologous landmarks used in other fish morphometric studies (Dornburg et al. 2011; Frederich et al. 2012) were used to capture body shape variation (Figure 2A). Briefly these are: (1) posteroventral corner of the maxilla; (2) anteroventral tip of the premaxilla; (3) anterodorsal point of mouth where fleshy lip meets scales; (4) most anterior point of eye; (5) most dorsal point of eye; (6) most posterior point

191 of eye; (7) most ventral point of eye; (8) center of eye; (9) anterior point of first dorsal spine

192 insertion; (10) dorsal fin origin; (11) anterior point where dorsal fin sheath joins fin rays; (12) dorsal fin insertion; (13) dorsal inflection of caudal peduncle; (14) dorsal caudal-fin ray insertion; (15) ventral caudal-fin ray insertion; (16) ventral inflection of caudal peduncle; (17) anal fin insertion; (18) anal fin origin, (19) posterior inflection where pelvic flap meets body;

196 (20) posterior point of pelvic spine insertion; (21) anterior point of pelvic spine insertion; (22) posterior ventral point where fleshy lower lip meets scales; (23) anterodorsal point of lower jaw; (24) dorsal point where pectoral fin base joins body; (25) dorsal point of pectoral fin ray insertion; (26) ventral point of pectoral fin ray insertion; (27) ventral point where pectoral fin base joins body. To better capture the curves of the body between landmarks, five sliding semilandmarks were placed as follows: (1) at the midpoint between landmarks 3 and 9; (2) at the midpoint of the dorsal fin, placed along the body; (3) at the midpoint between the dorsal and ventral caudal fin ray insertions, placed along the fin ray insertion margin; (4) at midpoint of the anal fin, placed along the body; and (5) at the midpoint between landmarks 21 and 22. 
207 Linear measurements were taken on each digitized specimen using the ImageJ software package

208 (Abràmoff et al. 2004). For each digitized specimen, the images of corresponding to maximum

209 jaw opening were used to measure standard length, maximum protrusion of the premaxilla,

210 length of the mandible, and maximum gape size. Since pinfish ecomorphs are divided into

211 groups that reflect changes in jaw morphology correlated with changes between bottom and

212 water column feeding (Ruehl et al. 2011), we additionally quantified three angles to assess the

213 mouth position of each specimen during feeding (Figure 2B). The downward angle of the upper

214 jaw was measured drawing a line along the ventral margin of the head just dorsal to the maxilla,

215 down the dorsal margin of the premaxilla, to a termination at the most anterior point of the

216 premaxilla (Figure 2B). Similarly, the angle of the lower jaw was measured by drawing a line

217 along the ventral margin of each specimen from the operculum to the angular, with a connecting

218 segment connecting to the most anterior point of the dentary along its ventral margin (Figure

219 2B). Changes in the midpoint of the jaw position were quantified by drawing a line along the

220 ventral margin of the head just dorsal to the maxilla from it's most anterior to its most ventral

221 point, with a connecting segment to the most ventral point of the premaxilla (Figure 2B).

222

223 Statistical Analysis

224 To test for sexual dimorphism in our three trait datasets we used a combination of 225 principle component analysis (PCA) and multivariate analysis of variance (MANOVA). For the

226 body shape data, a Procrustes fit was first used to remove variation due to scaling, rotation, and

227 translation (Rohlf and Slice 1990; Zelditch et al. 2012) in the body shape data. Procrustes

228 coordinates were subjected to a PCA implanted in the R package geomorph (Adams and

229 Otárola-Castillo 2013). Although relative warps analyses are often alternatively applied to 
230 coordinate data (Bastir and Rosas 2006; Sidlauskas 2008; Dornburg et al. 2011), a PCA is

231 equivalent to a relative warps analysis with an alpha set to 0 (Rohlf 1993, Birch 1997).

232 For both the jaw dataset comprising linear and angle measurements, and the

233 hematological dataset, data were log transformed and first regressed against log body size to

234 account for the possibility of allometry. To account for the possibility of different allometric

235 trends between males and females, regressions were conducted with the trait data separated by

236 sex. A PCA was then conducted on the residuals of the regressions for each dataset. Morpho- and

237 hematospaces were generated for each PCA by plotting the orthogonal eigenvectors that

238 correspond with the major axes of shape variation, with convex hulls of the male and female data

239 plotted to visualize the degree of overlap. For each class of data, a MANOVA was used to

240 compare the PC axes that cumulatively summed to $95 \%$ of the variance between male and

241 female Lagodon rhomboides.

242 We built four models that compared the effect of (1) Feeding morphology; (2) Feeding

243 morphology with size as a covariate; (3) Body shape (PC1); and (4) a null intercept-only model

244 on each blood value trait. The fits of all models were simultaneously compared using general

245 linear models (Nelder and Baker 1972) in conjunction with an information theoretic framework

246 based on Akaike's Information Criterion (Akaike 1973) corrected for small sample size

247 (Burnham and Anderson 2002). Sample size corrected AICc weights $\left(w_{i}\right)$ and coefficients were

248 estimated using Akaike weight based model averaging across all models. For feeding ecology,

249 lower jaw angle was used as an alternative to qualitative assessment of how terminal versus

250 inferior the mouth position was. All analyses were conducted in R using the libraries bbmle

251 (Bolker 2010) and MuMIn (Barton and Barton 2015). 


\section{Results}

254

255

Hematological Values

256

Tables 1 and 2 display the biochemistry, blood gas, and hematology results for the 37

257

pinfish analyzed. We collected similar numbers of males and females (Table 1), with the values

of all parameters overlapping between sexes (Figure S1). In a few samples the iSTAT blood

259

analyzer was unable to calculate the values for some of the parameters resulting in slightly

260

smaller n (Table 1). Also, for certain parameters, the iSTAT indicated values that exceeded the

261

maximum detectable (Table 1). For the purpose of calculating a mean group value the maximum

262

recordable value was used. While this yields a lower estimate of the mean than actually exists

263

within the data, the low numbers of samples above the maximum recordable level (Table 1)

264 likely produce only a minor skew to the estimated distribution of variation as measurable values

265 remained well between the first and third quartiles (Table 1).

266

267

Statistical Analysis of Sexual Dimorphism

268

Pinfish measured ranged in size between 93.8 and $168 \mathrm{~mm}\left(\right.$ median=137.7 $\mathrm{mm} ; 1^{\text {st }}$

269

quartile $=130.5 \mathrm{~mm}, 3^{\text {rd }}$ quartile $=150.6 \mathrm{~mm}$ ) and in weight between 11 and 148 grams

270

$\left(\right.$ median=80 g; $1^{\text {st }}$ quartile $=58 \mathrm{~g}, 3^{\text {rd }}$ quartile $\left.=93 \mathrm{~g}\right)$. Jaws measured displayed a $20^{\circ}$ and $30^{\circ}$

271

range of angles for the upper and lower jaws respectively, with no predicted relationship between

272 jaw angle and size (Table S1), corresponding with previous work demonstrating substantial

273 differences in jaw orientation in relation to habitat not allometry (Ruehl et al. 2011).

274

Principle component analysis of the body shape data provided no evidence of sexual

275 dimorphism. Principle component axes one through five respectively captured 24, 17, 7, 6, and 5 
276 percent of the cumulative variance with the first axis of body shape change describing an

277 elongation of the caudal peduncle coupled with an anterodorsal widening of the cranium (Figure

278 3A). The second PC axis described changes in the anterior slope of the cranium coupled with an 279 anteroposterior elongation of the body and cranium (Figure 3A). There was no clear separation 280 of male and female body shapes in morphospace with a MANOVA on the PC scores finding no 281 significant effect of sex on body shape (Pillai's trace $=0.485, F=1.79, p=0.082$ ).

282 Similarly, there was no clear separation of male and females in either the jaw 283 morphospace (Figure 3B) or the hematospace (Figure 3C). In the jaw PCA, the first three PC 284 axes captured 87 percent of the variance $(\mathrm{PC} 1=56 \%$; $\mathrm{PC} 2=19 \%$; $\mathrm{PC} 3=12 \%)$ while a PCA of 285 the hematological data yielded three axes that together described $85 \%$ of the cumulative variance $286(\mathrm{PC} 1=48 \% ; \mathrm{PC} 2=26 \% ; \mathrm{PC} 3=11 \%)$. A MANOVA on the PC scores mirrored the qualitative 287 results of the morphospaces and provided no support for a significant effect of sex on jaw 288 morphology (Pillai's trace $=3.94 \mathrm{e}-30, \mathrm{~F}=4.95 \mathrm{e}-29, \mathrm{p}=1$ ) or of sex on the health assessment 289 data (Pillai's trace $=5.44 \mathrm{e}-31, \mathrm{~F}=4.35 \mathrm{e}-30, \mathrm{p}=1$ ). Taken together, there is little evidence for 290 sexual dimorphism in this sample of pinfish.

\section{The Effect of Ecomorphology on Health Assessment Data}

293 There is no evidence that ecomorphology (Table 3) or size (Table S2) represent the processes 294 that generate the health assessment data. For the majority of blood traits that included sodium, 295 potassium, calcium, glucose, the partial pressure of carbon dioxide, and saturated oxygen 296 content, the best-fitting model was the null, intercept-only model (Table 3). While the model 297 selection approach revealed some uncertainty in model choice with $\triangle \mathrm{AICc}$ values less than 2 298 between null and second best model (Burnham and Anderson 2002, Burnham and Anderson 
299 2004), quantification of the model-averaged estimates for all predictors across all models in the

300 set ubiquitously yielded no evidence for a relationship between ecomorphology and hematology

301 (Table 3).

302

303 Discussion

304 The results of our health assessment correspond with published work and provide new

305 baseline information on additional blood parameters that can be used for monitoring the health

306 status of this ecologically important species. We find no evidence for sexual dimorphism in

307 either the morphological or hematological and biochemical datasets, consistent with previous

308 studies that have found no sexual dimorphism in this species (Nelson 2002).Integrating our

309 health assessment with the morphological analyses we also find no evidence for a strong

310 relationship between blood physiology and feeding morphology. Comparing our results to

311 published values from other fish species support hypotheses concerning patterns of hematocrit,

312 lactate, and glucose content across marine fishes.

313

314 Towards developing baseline health statistics for wild pinfishes

315 Our analyses found no evidence for a relationship between blood parameters and either

316 sex or quantified aspects of feeding ecology. Sexually dimorphic aspects of blood physiology

317 have been documented across a diversity of vertebrates spanning fishes to mammals. For

318 example, sexual dimorphism in hemoglobin and red blood cell counts have been found in the

319 New World monkey Cebus apella (Rosner et al. 1985; N=40) while hematocrit was found to

320 vary significantly between male and female individuals of the shad Tenualosa ilisha (Jawad et al.

321 2004; N=400). However, our results yielded no support for a relationship between any blood

322 parameter and sex (Figure 3 \& Figure S1). Given the overlap between sexes of each measured 
323 parameter (Figure 3 \& Figure S1), this is unlikely a reflection of low sample size. Instead our

324 inability to detect a relationship between sex and blood physiology in our study may be expected.

325 Changes in hematology have been found to correspond with expected changes in the demands of

326 hematological functions at different body masses (Burggren et al. 1987) and sexual size

327 dimorphism has been demonstrated for both Cebus apella (Masterson et a. 1998; Kay et al.

328 1998) and Tenualosa ilisha (Jafri et al. 1999). In contrast to these taxa, pinfish are not known to

329 exhibit any degree of sexual size dimorphism (Nelson 2002), a finding consistent with our

330 morphological analyses (Figure 3) even when accounting for potential variation due to patterns

331 of allometry (Tables S1 and S2). Our findings are in line with previous blood work on this

332 species that found no evidence for a relationship between sex and blood characteristics (Cameron

333 1970). However, there are several reasons to expect that ecomorphology associated with habitat

334 specificity could underlie hematological and biochemical differences.

335 Simple sand habitats are associated with more active roaming in pinfishes (Ruehl et al.

336 2011), and a previous laboratory experiment linked increased activity with increased blood

337 concentrations in this species (Cameron 1970). This expectation of increased locomotor activity

338 in sand habitats raises the question of whether sand habitat fidelity would promote detectable

339 differences in blood physiology. As low sample sizes will bias towards simpler model fits given

340 the penalty factor in a AICc framework (Burnham and Anderson 2002), our inability to provide

341 evidence for a link between ecomorphology and blood physiology could be an artifact of

342 experimental design. Although are sample sizes are on par with other studies of fishes (e.g.,

343 Fazio et al.; $\mathrm{n}=25$ ), this is certainly plausible. However, we find sample size an unlikely

344 explanation given the broad overlap of blood parameters and ecomorphology (Figure S3).

345 Alternatively, potentially confounding the expectation of habitat-specific differentiation of blood 
346 parameters is the observation that in more complex eel-grass dominated patches pinfishes focus

347 foraging and feeding across a wider range of the water column, requiring continual fine-scale

348 maneuvering (Ruehl et al. 2011). In the absence of studies investigating the energetics of

349 pinfishes in different habitat types, it is unclear how different these exercise regimes between

350 habitats really. Further, a not mutually exclusive hypothesis is that the mosaic nature of our

351 collection site facilitates pinfish to opportunistically forage in both sandy and eel-grass

352 dominated patches.

353 During our assessment multiple individuals representing the extremes of the measured

354 variation were collected at the same exact (sand bottom) site, providing some evidence of

355 migration between habitat patches. While juvenile pinfish show high site fidelity (Potthoff and

356 Allen 2003), movement patterns of adults are not known. Although a detailed study of pinfish

357 activity patterns is outside the scope of our study, comparisons of our data with future data

358 collected at habitat homogenous sites will offer a way to disentangle the possible effect of

359 heterogeneous foraging patterns on baseline hematological and biochemical data. Likewise,

360 integrating our study with a further investigation of juvenile fishes offers another unexplored

361 axis of potential variation, as there was too little extractable blood within juveniles below $71 \mathrm{~mm}$

362 for the instruments used in this study forcing us to restrict our sampling to adults, many of which

363 are considered large for the species (Muncy 1984). Regardless of possible mechanisms

364 underlying the patterns of pinfish ecophysiology in our data, our findings contribute new

365 baseline data and provide new axes of inquiry in future investigations of sources that underlie

366 variation in blood physiology across the range of this important Atlantic fish.

367

368 Pinfish in the perspective of marine fish physiology 
370 (Near et al. 2012b, Eschmeyer and Fricke 2015), with over 17,000 species found in marine

371 waters (Vega and Wiens 2012). Although collecting baseline data across a quarter of living

372 vertebrates is a task that will take several decades, existing work within pinfishes (Cameron

373 1970) as well as several recent investigations of marine teleosts (Fazio et al. 2012; Francesco et

374 al. 2012; Fazio et al. 2013) provide an early opportunity to compare other published blood

375 parameters to values from our study.

376 Intraspecifically, our hematocrit values closely mirror previously collected data

377 (Cameron 1970; Table 4). Hematocrit values are closely related to blood oxygen content

378 (Randall 1982), suggesting similar arterial blood composition between populations. Our

379 differential white blood cell count (WBC) also closely matches previous work by Cameron

380 (1970), who found a wide range of variation, from 9.41 to $47.36 \times 10^{3} / \mu 1$. Our pinfish WBC

381 counts were similar in that the average total WBC count was $25.78 \times 103 / \mu 1$, ranging from 6.8 to

$38273.2 \times 103 / \mu 1$. As the defensive cells of the body, WBC levels have implications for immune

383 response, and the ability of the animal to fight infection, with higher levels correlated with more

384 effective immune responses (Douglass and Jane 2010). These wide ranges of WBC across two

385 independent studies are enigmatic. While leucocrit is related to stress tolerances of individuals,

386 such as physiological stress due to handling and temperature changes, WBC's are relatively

387 insensitive to physiological sampling procedures (Wedemeyer et al. 1983). This wide range

388 could be attributed to immune function, heterogeneous environmental stressors, or even possibly

389 infection or disease. More work is clearly needed to determine why pinfishes exhibit a WBC

390 range spanning nearly an order of magnitude. 
392 teleost fish species (Fazio et al. 2013), the hematocrit, hemoglobin, and lactate values most

393 closely matched those of the flathead grey mullet (Mugil cephalus; Table 4). Fazio et al. (2013)

394 also found that blood lactate concentrations were higher in more active fish, such as European

395 sea bass (Dicentrarchus labrax) and mullet, compared to less active species (Table 4). The

396 pinfish mean lactate value from our study was comparable to that of an active fish (Table 4),

397 however glucose levels for this species differed substantially from both the European sea bass

398 and mullet assessed by Fazio et al. (2013). While glucose measurements can vary greatly

399 between analytical method and instrument, this large difference may reflect increasing carnivory

400 impairing the ability to clear excess blood glucose levels (Cowey et al. 1977). Many carnivorous

401 fish have been traditionally considered relatively glucose-intolerant species (Wilson 1994; Moon

402 2001), a hypothesis in line with the results of Fazio et al. (2013) who found the highest levels of

403 glucose in the carnivorous European seabass and lowest in the herbivorous mullet. Since pinfish

404 are omnivores (Montgomery and Targett 1992), their glucose levels fall in the middle of this

405 range, with values being closer to those of the omnivorous Gobius niger than the herbivorous $M$.

406 cephalus.

407 Although taxonomic sampling is currently limited in marine fish hematological and

408 biochemical studies, a comparison of our study with the results of Fazio et al. (2013) suggests

409 that broad "ecohematological" patterns may well exist across the ray finned fish Tree of Life.

410 Since the success of fishes is linked to their ability to diversify within any aquatic habitat type

411 (Near et al. 2013), continual case studies of individual species will facilitate future investigations

412 of correlations between blood value variation and ecology, and ultimately provide the necessary

413 data to place fish blood physiology into a phylogenetic perspective. Such a historic perspective 
414 will not only help characterize the severity of physiological changes following different stress

415 conditions, such as exposure to pollutants, disease, metals, hypoxia, and other stressors (Blaxhall

416 1972; Duthie and Tort 1985), but shed light on patterns of convergence in the physiological

417 changes that underlie the successful diversification of fishes. As we move further in the $21^{\text {st }}$

418 century, there is a growing consensus that marine fish species are valuable indicators from which

419 to assess changes in ocean conditions in response to a variety of factors (Schlacher et al. 2007).

420 Continual health assessments both within and between species will be pivotal to monitoring the

421 health of the world's oceans and offer the opportunity to gleen new insights into physiological

422 processes that govern the origin and maintenance of marine biodiversity.

423

424 Acknowledgements

425 We would like to thank A. Lamb and Dr. K. Thompson for help catching pinfish in the field. We

426 would also like to thank Dr. K. Thompson, Dr. B. Phillips, and Dr. C. Harms for all of their help

427 with the lab work. Dr. D. Warren and Dr. T. Iglesias provided valuable help and code for the

428 general linear model analyses and R. Morris provided additional help with other statistical

429 analyses.. Dr. A. Camus assisted with deciphering blood samples and offering lab space in which

430 to do hematological counts. We thank G. Hogue, L. Roupe, and L. Lukas for help with specimen

431 curation. We would like to thank K. Passingham for logistical support and equipping us with the

432 tools needed for the lab work. All data has been archived on Zenodo (DOI pending acceptance).

\section{References}

Abràmoff M, Magalhães PJ, Ram SJ (2004) Image processing with ImageJ. Biophotonics Internat 11:36-42. 
439

440

441

442

443

444

445

446

447

448

449

450

451

452

453

454

455

456

457

458

459

460

461

462

463

464

465

466

467

468

469

470

471

472

473

474

475

476

477

478

479

480

481

482
Adams CM, Lazur AM, Zajicek P, Zimet D (1998) An assessment of the market for live marine baitfish in Florida. Bureau of Seafood and Aquaculture, Florida Department of Agriculture and Consumer Services. Florida Sea Grant College Program 97:1-33.

Adams DC, Otárola-Castillo E (2013) Geomorph: an R package for the collection and analysis of geometric morphometric shape data. Methods in Ecol Evol 4:393-399.

Adams DC, Rohlf FJ, Slice DE (2004) Geometric morphometrics: ten years of progress following the 'revolution'. Italian J Zool 71:5-16.

Adhikari S, Sarkar B, Chatterjee A, Mahapatra C, Ayyappan S (2004) Effects of cypermethrin and carbofuran on certain hematological parameters and prediction of their recovery in a freshwater teleost, Labeo rohita (Hamilton). Ecotox Environ Safety 58:220-226.

Akaike H (1973) Information theory and an extension of the maximum likelihood principle. In: International Symposium on Information Theory, 2nd, Tsahkadsor, Armenian SSR 267281.

Albins MA, Hixon MA (2013) Worst case scenario: potential long-term effects of invasive predatory lionfish (Pterois volitans) on Atlantic and Caribbean coral-reef communities. Environ Biol Fishes 96:1151-1157.

Allender MC, Fry MM (2008) Amphibian hematology. Veterinary Clinics of North America: Exotic Anim Pract 11:463-480.

Anderson E, Stoskopf M, Morris Jr M, Clarke E, Harms C (2010) Hematology, plasma biochemistry, and tissue enzyme activities of invasive red lionfish captured off North Carolina, USA. J Aquat Anim Health 22:266-273.

Arnold JE (2005) Hematology of the sandbar shark, Carcharhinus plumbeus: standardization of complete blood count techniques for elasmobranchs. Vet Clin Path 34:115-123.

Barton K, Barton MK (2015) Package 'MuMIn’. Version 1:18.

Bastir M, Rosas A (2006) Correlated variation between the lateral basicranium and the face: a geometric morphometric study in different human groups. Arch Oral Biol 51:814-824.

Baum JK, Myers RA, Kehler DG, Worm B, Harley SJ, Doherty PA (2003) Collapse and conservation of shark populations in the Northwest Atlantic. Science 299:389-392.

Becker EL, Bird R, Kelly JW, Schilling J, Solomon S, Young N (1958) Physiology of marine teleosts. II. Hematologic observations. Physiol Zool:228-231. 
483

484

485

486

487

488

489

490

491

492

493

494

495

496

497

498

499

500

501

502

503

504

505

506

507

508

509

510

511

512

513

514

515

516

517

518

519

520

521

522

523

524

525

526

527

Bethea DM, Carlson JK, Buckel JA, Satterwhite M (2006) Ontogenetic and site-related trends in the diet of the Atlantic sharpnose shark Rhizoprionodon terraenovae from the northeast Gulf of Mexico. Bull Mar Sci 78:287-307.

Birch JM (1997) Comparing wing shape of bats: the merits of principal-components analysis and relative-warp analysis. J Mammal 78:1187-1198.

Bolker B (2010) bbmle: Tools for general maximum likelihood estimation. R package version 0.9 .

Bonilla-Gómez JL, López-Rocha JA, Badillo-Alemán M, Tzeek-Tuz J, Chiappa-Carrara X (2011) Growth and mortality of Lagodon rhomboides (Pisces: Sparidae) in a tropical coastal lagoon in northwestern Yucatan, Mexico. Revista Ciencias Marinas y Costeras 3:99-109.

Bookstein FL (1997) Morphometric tools for landmark data: geometry and biology. Cambridge University Press.

Brenner DG, Lewbart M, Stebbins, Herman DW (2002) Health survey of wild and captive bog turtles (Clemmys muhlenbergii) in North Carolina and Virginia. J Zoo Wildl Med 33:311316.

Brill R, Bushnell P, Schroff S, Seifert R, Galvin M (2008) Effects of anaerobic exercise accompanying catch-and-release fishing on blood-oxygen affinity of the sandbar shark (Carcharhinus plumbeus, Nardo). J Exp Mar Biol Ecol 354:132-143.

Burggren WW, Dupré RK, Wood SC (1987) Allometry of red cell oxygen binding and hematology in larvae of the salamander, Ambystoma tigrinum. Resp Physiol 70:73-84.

Burnham KP, Anderson DR (2002) Model selection and multimodel inference: a practical information-theoretic approach. Springer, New York.

Burnham KP, Anderson DR (2004) Multimodel inference: Understanding AIC and BIC in model selection. Sociol Methods Res 33:261-304.

Cameron JN (1970) The influence of environmental variables on the hematology of pinfish (Lagodon rhomboides) and striped mullet (Mugil cephalus). Comp Biochem Physiol 32:175-192.

Cnaani AS, Tinman Y, Avidar, M. Ron, and G. Hulata (2004) Comparative study of biochemical parameters in response to stress in Oreochromis aureus, O. mossambicus and two strains of O. niloticus. Aquacult Res 35:1434-1440.

Dardeau, MR, McDonald, CM. (2007) Pressure related incidence rates in scientific divng. In: Pollock NW, Godfrey, JM, editors. Diving for Science 2007. Proceedings of the 
528

529

530

531

532

533

534

535

536

537

538

539

540

541

542

543

544

545

546

547

548

549

550

551

552

553

554

555

556

557

558

559

560

561

562

563

564

565

566

567

568

569

570

571

572

573

American Academy of Underwater Sciences $26^{\text {th }}$ Symposium, Dauphin Island, AL: American Academy of Underwater Sciences;2007. p. 111-115.

DiMaggio, MA, Broach JS, Ohs CL (2013) Evaluation of Ovaprim and human chorionic gonadotropin doses on spawning induction and egg and larval quality of pinfish, Lagodon rhomboides. Aquacult 414:9-18.

DiMaggio MA, Grabe SW, DeSantis SM, Ohs CL (2010) Induced volitional spawning and larval rearing of pinfish. N Amer J Aquacult 72:252-257.

Dornburg A, Sidlauskas B, Santini F, Sorenson L, Near TJ, Alfaro ME (2011) The influence of an innovative locomotor strategy on the phenotypic diversification of triggerfish (Family: Balistidae). Evol 65:1912-1926.

Dove AD, Arnold J, Clauss TM (2010) Blood cells and serum chemistry in the world's largest fish: the whale shark Rhincodon typus. Aquat Biol 9:177-183.

Elahee K, Bhagwant S (2007) Hematological and gill histopathological parameters of three tropical fish species from a polluted lagoon on the west coast of Mauritius. Ecotox Environ Safety 68:361-371.

Eschmeyer WN, Fricke R, eds. (2015) Catalog of fishes electronic version (9 Sept 2015). http://research.calacademy.org/research/ichthyology/catalog/fishcatmain.asp. California Academy of Sciences, San Francisco.

Fabry VJ, Seibel BA, Feely RA, Orr JC (2008) Impacts of ocean acidification on marine fauna and ecosystem processes. ICES J Mar Sci: J du Conseil 65:414-432.

Fazio F, Faggio C, Marafioti S, Torre A, Sanfilippo M, Piccione G (2012) Comparative study of haematological profile on Gobius niger in two different habitat sites: Faro Lake and Tyrrhenian Sea. Cahiers de Biologie Marine 53:213-219.

Fazio F, Marafioti S, Arfuso F, Piccione G, Faggio C (2013) Comparative study of the biochemical and haematological parameters of four wild Tyrrhenian fish species. Veterinarni Medicina 58:576-581.

Francesco F, Satheeshkumar P, Kumar DS, Caterina F, Giuseppe P (2012) A comparative study of hematological and blood chemistry of Indian and Italian grey mullet (Mugil cephalus Linneaus 1758). HOAJ Biology 1:5.

Frederich B, Sorenson L, Santini F, Slater GJ, Alfaro ME (2012) Iterative ecological radiation and convergence during the evolutionary history of damselfishes (Pomacentridae). Amer Nat 181:94-113.

Friedrichs, K. R., Harr, K. E., Freeman, K. P., Szladovits, B., Walton, R. M., Barnhart, K. F., \& Blanco-Chavez, J. (2012). ASVCP reference interval guidelines: determination of de 
574

575

576

577

578

579

580

581

582

583

584

585

586

587

588

589

590

591

592

593

594

595

596

597

598

599

600

601

602

603

604

605

606

607

608

609

610

611

612

613

614

615

616

617

618 novo reference intervals in veterinary species and other related topics. Veterinary Clinical Pathology, 41, 441-453.

Groff J, Zinkl J (1999) Hematology and clinical chemistry of cyprinid fish. Common carp and goldfish. Vet Clin N Amer Exot Anim Pract 2:741-776.

Haman KH, Norton TM, Thomas AC, Dove AD, Tseng F (2012) Baseline health parameters and species comparisons among free-ranging Atlantic sharpnose (Rhizoprionodon terraenovae), bonnethead (Sphyrna tiburo), and spiny dogfish (Squalus acanthias) sharks in Georgia, Florida, and Washington, USA. Journal of Wildlife Diseases 48:295-306.

Hansen DJ (1969) Food, growth, migration, reproduction, and abundance of pinfish, Lagodon rhomboides, and Atlantic croaker, Micropogon undulatus, near Pensacola, Florida, 196365. Fish Bull 68:135-146.

Harvell CD, Mitchell CE, Ward JR, Altizer S, Dobson AP, Ostfeld RS, Samuel MD (2002) Climate warming and disease risks for terrestrial and marine biota. Science 296(5576): 2158-2162.

Hoegh-Guldberg O, Mumby P, Hooten A, Steneck R, Greenfield P, Gomez E, Harvell C, Sale P, Edwards A, Caldeira K (2007) Coral reefs under rapid climate change and ocean acidification. Science 318:1737-1742.

Horn, P. S., Feng, L., Li, Y., \& Pesce, A. J. (2001). Effect of outliers and nonhealthy individuals on reference interval estimation. Clinical Chemistry,47: 2137-2145.

Jafri, S. I. H., Narejo, N. T., Baloch, W. A., \& Sahato, G. A. (1999) Studies on Land-Locked Population of Palla, Tenualosa ilisha from Keenjhar Lake (Sindh), Pakistan. Pakistan Journal of Zoology (31): 347-350.

Jawad L, Al-Mukhtar M, Ahmed H (2004) The relationship between haematocrit and some biological parameters of the Indian shad, Tenualosa ilisha (Family Clupeidae). Anim Biodiver Conserv 27:47-52.

Kay, R. F., Plavcan, J. M., Glander, K. E., \& Wright, P. C. (1988). Sexual selection and canine dimorphism in New World monkeys. American Journal of Physical Anthropology, 77: 385-397.

Levin P, Petrik R, Malone J (1997) Interactive effects of habitat selection, food supply and predation on recruitment of an estuarine fish. Oecologia 112:55-63.

Lewbart GA, Hirschfeld M, Denkinger J, VascoK, Guevara N, García J, Muñoz J, Lohmann KJ (2014) Blood gases, biochemistry, and hematology of Galapagos green turtles (Chelonia mydas). PLoS ONE. 9(5): e96487. doi:10.1371/journal.pone.0096487 
619 Lohner TW, Reash RJ, Willet VE, Rose LA (2001) Assessment of tolerant sunfish populations

620

621

622

623

624

625

626

627

628

629

630

631

632

633

634

635

636

637

638

639

640

641

642

643

644

645

646

647

648

649

650

651

652

653

654

655

656

657

658

659

660

661

662

(Lepomis sp.) inhabiting selenium-laden coal ash effluents: Hematological and population level assessment. Ecotoxicol Environ Safety 50:203-216.

Luczkovich JJ (1988) The role of prey detection in the selection of prey by pinfish Lagodon rhomboides (Linnaeus). J Exp Mar Biol Ecol 123:15-30.

Maita M (2007) Fish health assessment. Dietary supplements for the health and quality of cultured fish. London: CABI Publishing:10-34.

Masterson, T. J., \& Hartwig, W. C. (1998). Degrees of sexual dimorphism in Cebus and other New World monkeys. American journal of physical anthropology, 107(3), 243-256.

Montgomery JL, Targett, TE (1992) The nutritional role of seagrass in the diet of the omnivorous pinfish Lagodon rhomboides (L.). J Exp Mar Biol Ecol 158:37-57.

Muncy RJ (1984) Species Profiles. Life Histories and Environmental Requirements of Coastal Fishes and Invertebrates (Gulf of Mexico). PINFISH. DTIC Document.

Mylniczenko ND, Harris B, Wilborn RE, Young FA (2007) Blood culture results from healthy captive and free-ranging elasmobranchs. J Aquat Anim Health 19:159-167.

Near TJ, Dornburg A, Eytan RI, Keck BP, Smith WL, Kuhn KL, Moore JA, Price SA, Burbrink FT, Friedman M (2013) Phylogeny and tempo of diversification in the superradiation of spiny-rayed fishes. Proc Nat Acad Sci 110:12738-12743.

Near TJ, Dornburg A, Kuhn KL, Eastman JT, Pennington JN, Patarnello T, Zane L, Fernandez DA, Jones CD (2012a) Ancient climate change, antifreeze, and the evolutionary diversification of Antarctic fishes. Proc Nat Acad Sci 109:3434-3439.

Near TJ, Dornburg A, Kuhn KL, Eastman JT, Pennington JN, Patarnello T, Zane L, Fernandez DA, Jones CD (2012b) Resolution of ray-finned fish phylogeny and timing of diversification. Proc Nat Acad Sci 109:13698-13703.

Nelder, JA, Wedderburn, RWM. (1972). Generalized linear models. J. R. Statist. Soc. A 135: $370-84$.

Nelson, G. A. (2002). Age, growth, mortality, and distribution of pinfish (Lagodon rhomboides) in Tampa Bay and adjacent Gulf of Mexico waters. Fishery Bulletin, 100: 582-592.

Newman S, Piatt J, White J (1997) Hematological and plasma biochemical reference ranges of Alaskan seabirds: their ecological significance and clinical importance. Colonial Waterbirds 492-504. 
663 Ohs CL, Grabe SW, DeSantis SM, DiMaggio MA, Rhyne AL (2010) Culture of pinfish at

664

665

666

667

668

669

670

671

672

673

674

675

676

677

678

679

680

681

682

683

684

685

686

687

688

689

690

691

692

693

694

695

696

697

698

699

700

701

702

703

704

705

706

707

708 different stocking densities and salinities in recirculating aquaculture systems. N Amer J Aquacult 72:132-140.

Orr JC, Fabry VJ, Aumont O, Bopp L, Doney SC, Feely RA, Gnanadesikan A, Gruber N, Ishida A, Joos F (2005) Anthropogenic ocean acidification over the twenty-first century and its impact on calcifying organisms. Nature 437:681-686.

Orth RJ, Heck KL (1980) Structural components of eelgrass (Zostera marina) meadows in the lower Chesapeake Bay-fishes. Estuaries 3:278-288.

Potthoff MT, Allen DM (2003) Site fidelity, home range, and tidal migrations of juvenile pinfish, Lagodon rhomboides, in salt marsh creeks. Environ Biol Fishes 67:231-240.

Randall D (1982) The control of respiration and circulation in fish during exercise and hypoxia. J Exp Biol 100:275-288.

Reid Jr. GK (1954) An ecological study of the Gulf of Mexico fishes, in the vicinity of Cedar Key, Florida. Bull Mar Sci 4:1-12.

Robins CR, Ray GC (1986) A field guide to Atlantic coast fishes of North America. Houghton Mifflin Company, Boston, U.S.A. 354 pp.

Rohlf FJ (1993) Relative warp analysis and an example of its application to mosquito wings. In: Marcus LF, Bello E, Valdecasas AG (eds.) Contributions to Morphometrics 8:131.

Rohlf FJ (2005) tpsDig, digitize landmarks and outlines, version 2.05. Department of Ecology and Evolution, State University of New York at Stony Brook.

Rohlf FJ, Slice D (1990) Extensions of the Procrustes method for the optimal superimposition of landmarks. Syst Biol 39:40-59.

Rosner J, Schinini A, Rovira T, Merlo R, Bestard R, Maldonado M (1985) Body measurements, hematology, and serum chemistry values of the adult Cebus apella monkey. J Med Primatol 15:295-302.

Ruehl CB, Shervette V, Dewitt TJ (2011) Replicated shape variation between simple and complex habitats in two estuarine fishes. Biol J Linn Soc 103:147-158.

Saravanan M, Kumar KP, Ramesh M (2011) Haematological and biochemical responses of freshwater teleost fish Cyprinus carpio (Actinopterygii: Cypriniformes) during acute and chronic sublethal exposure to lindane. Pest Biochem Physiol 100:206-211.

Satheeshkumar P, Ananthan G, Kumar DS, Jagadeesan L (2012) Haematology and biochemical parameters of different feeding behaviour of teleost fishes from Vellar estuary, India. Comp Clin Pathol 21:1187-1191. 
709

710

711

712

713

714

715

716

717

718

719

720

721

722

723

724

725

726

727

728

729

730

731

732

733

734

735

736

737

738

739

740

741

742

743

744

745

746

747

748

749

750

751

752

753

754

Schiel, DR, Steinbeck JR, Foster MS (2004) Ten years of induced ocean warming causes comprehensive changes in marine benthic communities. Ecol 85:1833-1839.

Schmidt TW(1986) Food of young juvenile lemon sharks, Negaprion brevirostris (Poey), near Sandy Key, western Florida Bay. Florida Scientist 49:7-10.

Seaward M (1994) Measuring up to disaster: the necessity for valid baseline data. Disaster Prev Manag: An International Journal 3(4): 17-26.

Shapiro, S. S., \& Wilk, M. B. (1965). An analysis of variance test for normality (complete samples). Biometrika, 52, 591-611.

Sidlauskas B (2008)Continuous and arrested morphological diversification in sister clades of characiform fishes: a phylomorphospace approach. Evol 62:3135-3156.

Stachowicz JJ, Terwin JR, Whitlatch RB, Osman RW (2002) Linking climate change and biological invasions: ocean warming facilitates nonindigenous species invasions. Proc Nat Acad Sci 99:15497-15500.

Stoner A (1980) Perception and choice of substratum by epifaunal amphipods associated with seagrasses. Mar Ecol Prog Ser 3:105-111.

Stoner AW (1982) The influence of benthic macrophytes on the foraging behavior of pinfish, Lagodon rhomboides (Linnaeus). J Exper Mar Biol Ecol 58:271-284.

Stoner AW, Livingston RJ (1984) Ontogenetic patterns in diet and feeding morphology in sympatric sparid fishes from seagrass meadows. Copeia174-187.

Thatje SK, Anger JA, Calcagno GA. Lovrich H, Pörtner O, Arntz WE (2005) Challenging the cold: crabs reconquer the Antarc Ecol 86:619-625.

Thompson P, Tollit D, Corpe H, Reid R, Ross H (1997) Changes in haematological parameters in relation to prey switching in a wild population of harbour seals. Funct Ecol 743-750.

Tocidlowski M, Lewbart G, Stoskopf M (1997) Hematologic study of red pacu (Colossoma brachypomum). Vet Clin Pathol 26:119-125.

Vega GC, Wiens JJ (2012) Why are there so few fish in the sea? Proc Royal Soc B-Biol Sci 279:2323-2329.

Watson L, Shechmeister I, Jackson L (1963) The hematology of goldfish, Carassius auratus. Cytologia 28:118-130.

Wedemeyer G, Gould R, Yasutake W (1983) Some potentials and limits of the leucocrit test as a fish health assessment method. J Fish Biol 23:711-716. 
755

756

757

758

759

760

761

762

763

764

765

766

767

768

769

770

771

772

773

774

775
Wilhelm Filho D, Eble GJ, Kassner G, Caprario FX, Dafré AL, Ohira M (1992) Comparative hematology in marine fish. Comp Biochem Physiol Part A: Physiol 102:311-321.

Willis TJ., Miller RB, Babcock RB (2000) Detection of spatial variability in relative density of fishes: comparison of visual census, angling, and baited underwater video. Mar Ecol Prog Ser 198:249-260.

Zelditch ML, Swiderski DL, Sheets HD (2012) Geometric morphometrics for biologists: a primer. Elsevier, San Diego. 
776

777

778

779

780

781

782

783

784

785

786

787

788

789

790

791

792

793

794

\section{Figure Legends}

Figure 1: Blood smear illustrating the different cell types (Wright-Giemsa stain, 1000X).

Figure 2: (A) Placement of homologous landmarks (light circles) and sliding semi-landmarks (dark circles). (B) Linear and angular jaw measurements taken from each individual.

Figure 3: Visualizations of the first two principle component axes for changes in (A) body shape quantified by the geometric morphometric analyses; (B) jaw morphology; and (C) hematological data. Outlines correspond to the convex hull of the morphospace for female (dark) and male (light) individuals respectively. Inserts in panel A represent changes in shape associated with the extremes of the first two principle component axes. 


\section{Tables}

Table 1: Descriptive statistics of the blood gas and blood biochemical values collected. $\mathrm{N}=$ number of samples, $\mathrm{m}=$ males, $\mathrm{f}=\mathrm{females}, \mathrm{SD}=\mathrm{standard}$ deviation, $\mathrm{Min}=$ minimum value, $\mathrm{Max}=$ maximum value, $\mathrm{OOR}=$ number of samples outside of the recordable range of our instruments, $\mathrm{RI}=\mathrm{reference} \mathrm{interval,} \mathrm{CI}=$ confidence interval. Reference Intervals were truncated with a lower bound of zero to maintain biological realism in non-negative blood parameters.

\begin{tabular}{|c|c|c|c|c|c|c|c|c|}
\hline Analyte & $N(\mathrm{~m} / \mathrm{f})$ & Mean, SD & $\begin{array}{c}\text { Quartile (25\%, } \\
50 \%, 75 \%)\end{array}$ & Min (OOR) & $\begin{array}{l}\text { Max } \\
\text { (OOR) }\end{array}$ & $\begin{array}{l}\text { Reference } \\
\text { Interval }\end{array}$ & $\begin{array}{c}90 \% \text { CI of } \\
\text { lower RI }\end{array}$ & $\begin{array}{c}90 \% \mathrm{CI} \text { of } \\
\text { upper RI }\end{array}$ \\
\hline $\mathrm{Na}(\mathrm{mmol} / \mathrm{L})$ & $37(14 / 17)$ & $168.84,7.04$ & $166,169,179$ & 156 & $>180(6)$ & $\begin{array}{c}154.0 \\
187.3\end{array}$ & $\begin{array}{c}149.4 \\
157.3\end{array}$ & $\begin{array}{l}183.3 \\
191.0\end{array}$ \\
\hline $\mathrm{K}(\mathrm{mmol} / \mathrm{L})$ & $31(14 / 12)$ & $4.7,1.4$ & $3.9,4.6,7.4$ & 3.1 & $>9.0(6)$ & $0.26,9.01$ & $0,1.28$ & $7.27,10.6$ \\
\hline $\begin{array}{l}\mathrm{iCa}(\mathrm{TC}) \\
(\mathrm{mmol} / \mathrm{L})\end{array}$ & $37(14 / 17)$ & $1.56,0.18$ & $\begin{array}{c}1.44,1.59 \\
1.66\end{array}$ & 1.23 & $>2.5(1)$ & $1.15,1.96$ & $1.04,1.23$ & $1.89,2.07$ \\
\hline $\begin{array}{l}\text { Glucose } \\
(\mathrm{mg} / \mathrm{dl})\end{array}$ & $37(14 / 17)$ & $169.7,101.43$ & $84,155,217$ & 45 & 419 & $0,373.9$ & 0,0 & 307,444 \\
\hline Hct $(\%)$ & $31(12 / 14)$ & $34.39,9.54$ & $30.5,34,37.5$ & 17 & 58 & $25.0,43.6$ & $22.2,27.6$ & $40.7,46.8$ \\
\hline $\mathrm{Hb}(\mathrm{g} / \mathrm{L})$ & $31(12 / 14)$ & $11.7,3.24$ & $\begin{array}{c}10.35,11.6 \\
12.75\end{array}$ & 5.8 & 19.7 & $8.59,14.8$ & $7.63,9.50$ & $13.9,15.9$ \\
\hline $\mathrm{pH}$ & $37(14 / 17)$ & $7,0.28$ & $\begin{array}{c}6.85,7.14 \\
7.32\end{array}$ & $<6.5(1)$ & 7.505 & $6.47,7.68$ & $6.30,6.62$ & $7.52,7.86$ \\
\hline Beecf & $36(14 / 16)$ & $-20.78,5.56$ & $\begin{array}{c}-29.25,-23.5,- \\
19.5\end{array}$ & $<-30(9)$ & -10 & $-37.5,-10.2$ & $-13.7,-5.1$ & $-40.0,-31.4$ \\
\hline $\begin{array}{c}\mathrm{HCO}^{3} \\
(\mathrm{mmol} / \mathrm{L})\end{array}$ & $36(14 / 16)$ & $7.52,3.07$ & $4.92,7.2,9.32$ & 3.3 & 13.8 & $0.52,13.4$ & $-0.97,2.36$ & $11.6,15.5$ \\
\hline $\mathrm{TCO}_{2}(\mathrm{mmHg})$ & $36(14 / 16)$ & $8.94,2.84$ & $6,8,11$ & $<5(6)$ & 14 & $1.97,14.0$ & $0.89,3.75$ & $12.1,16.0$ \\
\hline $\mathrm{sO}_{2} \%(\mathrm{mmHg})$ & $29(10 / 13)$ & $19.79,15.14$ & $6,16,32$ & 3 & 49 & $0,44.8$ & 0,0 & $34.2,56.5$ \\
\hline $\begin{array}{c}\text { Lactate } \\
(\mathrm{mmol} / \mathrm{L})\end{array}$ & $37(14 / 17)$ & $9.93,4.56$ & $6.4,9.9,13.9$ & 2 & 17.6 & $2.48,17.1$ & $0.63,4.29$ & $15.2,19.3$ \\
\hline PCV & $34(13 / 16)$ & $53.18,12.06$ & $45.25,50.5,60$ & 30 & 80 & $26.8,76.2$ & $20.4,32.7$ & $69.2,85.2$ \\
\hline
\end{tabular}


Table 2: Descriptive statistics of the manually analyzed hematology parameters collected. $\mathrm{N}=$ number of samples, $\mathrm{m}=\mathrm{males}, \mathrm{f}=\mathrm{females}, \mathrm{SD}=\mathrm{standard}$ deviation, $\mathrm{Min}=$ minimum value, Max = maximum value, $\mathrm{RI}=$ reference interval, $\mathrm{CI}=$ confidence interval. Reference Intervals were truncated with a lower bound of zero to maintain biological realism in non-negative blood parameters.

\begin{tabular}{|c|c|c|c|c|c|c|c|c|}
\hline Cell Type & $\mathrm{N}(\mathrm{m} / \mathrm{f})$ & Mean (SD) & Quartile $(25 \%, 50 \%, 75 \%)$ & Min & Max & $\begin{array}{c}\text { Reference } \\
\text { Interval }\end{array}$ & $\begin{array}{c}90 \% \text { CI of } \\
\text { lower RI }\end{array}$ & $\begin{array}{c}90 \% \text { CI of } \\
\text { upper RI }\end{array}$ \\
\hline Total WBC / ul & $30(14 / 13)$ & $\begin{array}{c}25,788 \\
(14,395.68)\end{array}$ & $16200,20000,32400$ & 6,800 & 73,200 & 0,54141 & 0,1647 & $\begin{array}{l}44684 \\
68230\end{array}$ \\
\hline Lymphocyte (\%) & $30(14 / 13)$ & $80.5(15.96)$ & $74.25,87,91$ & 39 & 96 & $52.1,123.0$ & $39.5,63.2$ & $113.6,135$ \\
\hline Neutrophil (\%) & $30(14 / 13)$ & $17.1(14.86)$ & $7,11,22.5$ & 2 & 54 & $0,44.0$ & 0,0 & $34.0,55.5$ \\
\hline Monocyte (\%) & $17(7 / 8)$ & $3.8(2.51)$ & $2,3,5$ & 0 & 11 & $0,8.72$ & $0,-5.78$ & $6.23,11.7$ \\
\hline
\end{tabular}


Table 3: Results of GLM fitting to test predictive power of morphological data on hematological parameters. Df= degrees of freedom, $\triangle \mathrm{AIC}=$ difference in $\mathrm{AIC}$ score between the model and the best-fitting model, wi $=\mathrm{AIC}$ weight, $\mathrm{df}=$ degrees of freedom, $\mathrm{WBC}=$ white blood cell count.

Set Response Variable Predictor Variable df $\triangle \mathrm{AICc} \quad w_{i} \quad$ Model-Averaged

\begin{tabular}{|c|c|c|c|c|c|c|}
\hline \multirow[b]{2}{*}{1} & & & & & \multicolumn{2}{|c|}{ Coefficients (95\% CI) } \\
\hline & Sodium & Intercept only & 2 & 0.0 & 0.43 & $-3.09 \mathrm{e}-4(-0.05,0.05)$ \\
\hline & Sodium & $\begin{array}{c}\text { Ecomorph (lower jaw } \\
\text { angle) }\end{array}$ & 3 & 0.8 & 0.31 & $0.09(-1.52,2.07)$ \\
\hline & Sodium & $\begin{array}{l}\text { Ecomorph (lower jaw } \\
\text { angle) } * \text { size }\end{array}$ & 5 & 5.5 & 0.24 & $0.115(-0.41,1.37)$ \\
\hline & Sodium & Body shape (PC1) & 3 & 10.6 & 0.02 & $-0.008(-1.55,0.92)$ \\
\hline \multirow[t]{4}{*}{2} & Potassium & Intercept only & 2 & 0.0 & 0.56 & $2.23 e-3(-0.46,0.47)$ \\
\hline & Potassium & $\begin{array}{c}\text { Ecomorph (lower jaw } \\
\text { angle) }\end{array}$ & 3 & 1.6 & 0.20 & $-0.476(-19.62,16.00)$ \\
\hline & Potassium & Body shape (PC1) & 3 & 2.4 & 0.09 & $-0.321(-10.67,6.95)$ \\
\hline & Potassium & $\begin{array}{l}\text { Ecomorph (lower jaw } \\
\text { angle) * size }\end{array}$ & 5 & 7.4 & 0.01 & $0.028(-13.11,17.26)$ \\
\hline \multirow[t]{4}{*}{3} & Calcium & Intercept only & 2 & 0.0 & 0.54 & $4.46 \mathrm{e}-4(-0.13,0.13)$ \\
\hline & Calcium & Body shape (PC1) & 3 & 1.3 & 0.28 & $0.431(-1.49,4.56)$ \\
\hline & Calcium & $\begin{array}{c}\text { Ecomorph (lower jaw } \\
\text { angle) }\end{array}$ & 3 & 2.4 & 0.16 & $-0.011(-5.36,5.23)$ \\
\hline & Calcium & $\begin{array}{l}\text { Ecomorph (lower jaw } \\
\text { angle) } * \text { size }\end{array}$ & 5 & 7.8 & 0.01 & $-0.001(-4.45,4.21)$ \\
\hline \multirow[t]{4}{*}{4} & Glucose & Intercept only & 2 & 0.0 & 0.56 & $4.90 \mathrm{e}-4(-0.71,0.71)$ \\
\hline & Glucose & $\begin{array}{l}\text { Ecomorph (lower jaw } \\
\text { angle) }\end{array}$ & 3 & 1.5 & 0.26 & $-0.544(-25.11,21.19)$ \\
\hline & Glucose & Body shape (PC1) & 3 & 2.4 & 0.17 & $-0.075(-14.09,13.18)$ \\
\hline & Glucose & $\begin{array}{l}\text { Ecomorph (lower jaw } \\
\text { angle) * size }\end{array}$ & 5 & 7.0 & 0.01 & 0.01(-18.36,19.49) \\
\hline \multirow[t]{4}{*}{5} & Hematocrit & $\begin{array}{c}\text { Ecomorph (lower jaw } \\
\text { angle) }\end{array}$ & 3 & 0.0 & 0.38 & $0.046(-0.65,0.74)$ \\
\hline & Hematocrit & Intercept only & 2 & 0.3 & 0.32 & $-2.457(-33.26,21.99)$ \\
\hline & Hematocrit & Body shape (PC1) & 3 & 0.9 & 0.24 & $0.993(-2.09,10.38)$ \\
\hline & Hematocrit & $\begin{array}{l}\text { Ecomorph (lower jaw } \\
\text { angle) } * \text { size }\end{array}$ & 5 & 3.9 & 0.06 & $0.356(-3.73,16.92)$ \\
\hline \multirow[t]{4}{*}{6} & Hemoglobin & $\begin{array}{c}\text { Ecomorph (lower jaw } \\
\text { angle) }\end{array}$ & 3 & 0.0 & 0.36 & $0.044(-0.64,0.73)$ \\
\hline & Hemoglobin & Intercept only & 2 & 0.2 & 0.34 & $-2.335(-33.01,21.92)$ \\
\hline & Hemoglobin & Body shape (PC1) & 3 & 0.8 & 0.25 & $0.993(-2.14,10.32)$ \\
\hline & Hemoglobin & $\begin{array}{l}\text { Ecomorph (lower jaw } \\
\text { angle) } * \text { size }\end{array}$ & 5 & 3.9 & 0.05 & $0.339(-3.77,16.9)$ \\
\hline \multirow[t]{4}{*}{7} & $\mathrm{pH}$ & Intercept only & 2 & 0.0 & 0.47 & $2.33 e-4(-0.05,0.05)$ \\
\hline & $\mathrm{pH}$ & Body shape (PC1) & 3 & 0.8 & 0.31 & $-0.188(-1.54,0.36)$ \\
\hline & $\mathrm{pH}$ & $\begin{array}{c}\text { Ecomorph (lower jaw } \\
\text { angle) }\end{array}$ & 3 & 1.7 & 0.20 & $-0.012(-2.23,2.12)$ \\
\hline & $\mathrm{pH}$ & $\begin{array}{l}\text { Ecomorph (lower jaw } \\
\text { angle) } * \text { size }\end{array}$ & 5 & 6.6 & 0.02 & $7.72 \mathrm{e}-3(-0.89,1.79)$ \\
\hline \multirow[t]{4}{*}{8} & $\mathrm{PCO} 2$ & Intercept only & 2 & 0.0 & 0.55 & $7.49 \mathrm{e}-4(-0.38,0.38)$ \\
\hline & $\mathrm{PCO} 2$ & Body shape (PC1) & 3 & 1.7 & 0.24 & $0.795(-4.73,11.33)$ \\
\hline & $\mathrm{PCO} 2$ & $\begin{array}{c}\text { Ecomorph (lower jaw } \\
\text { angle) }\end{array}$ & 3 & 2.0 & 0.20 & $-0.145(-14.67,13.33)$ \\
\hline & $\mathrm{PCO} 2$ & $\begin{array}{l}\text { Ecomorph (lower jaw } \\
\text { angle) } * \text { size }\end{array}$ & 5 & 7.4 & 0.01 & $3.69 \mathrm{e}-3(-11.73,11.18)$ \\
\hline \multirow[t]{3}{*}{9} & $\mathrm{PO} 2$ & Body shape (PC1) & 3 & 0.0 & 0.38 & $-6.51 e-3(-0.75,0.74)$ \\
\hline & $\mathrm{PO} 2$ & Intercept only & 2 & 0.2 & 0.33 & $-4.14(-24.82,2.88)$ \\
\hline & PO2 & Ecomorph (lower jaw & 3 & 0.7 & 0.27 & $0.906(-21.21,27.54)$ \\
\hline
\end{tabular}


angle)

\begin{tabular}{|c|c|c|c|c|c|c|}
\hline & $\mathrm{PO} 2$ & $\begin{array}{l}\text { Ecomorph (lower jaw } \\
\text { angle) * size }\end{array}$ & 5 & 6.1 & 0.02 & $-0.024(-21.08,18.33)$ \\
\hline \multirow[t]{4}{*}{10} & BEEcf & Intercept only & 2 & 0.0 & 0.55 & $4.45 e-4(-0.35,0.36)$ \\
\hline & BEEcf & $\begin{array}{c}\text { Ecomorph (lower jaw } \\
\text { angle) }\end{array}$ & 3 & 1.5 & 0.25 & $0.187(-11.15,12.52)$ \\
\hline & BEEcf & Body shape (PC1) & 3 & 2.3 & 0.18 & $-0.218(-8.12,5.62)$ \\
\hline & BEEcf & $\begin{array}{l}\text { Ecomorph (lower jaw } \\
\text { angle) * size }\end{array}$ & 5 & 7.0 & 0.02 & $0.012(-8.86,10.25)$ \\
\hline \multirow[t]{4}{*}{11} & Bicarbonate & Intercept only & 2 & 0.0 & 0.61 & $8.62 \mathrm{e}-4(-0.41,0.41)$ \\
\hline & Bicarbonate & $\begin{array}{c}\text { Ecomorph (lower jaw } \\
\text { angle) }\end{array}$ & 3 & 2.3 & 0.20 & $-0.178(-16.35,14.66)$ \\
\hline & Bicarbonate & Body shape (PC1) & 3 & 2.4 & 0.18 & $-0.013(-8.92,8.78)$ \\
\hline & Bicarbonate & $\begin{array}{l}\text { Ecomorph (lower jaw } \\
\text { angle) * size }\end{array}$ & 5 & 7.7 & 0.01 & $0.015(-11.3,13.54)$ \\
\hline \multirow[t]{4}{*}{12} & Total $\mathrm{CO} 2$ & Intercept only & 2 & 0.0 & 0.57 & $9.82 \mathrm{e}-4(-0.36,0.36)$ \\
\hline & Total CO2 & $\begin{array}{c}\text { Ecomorph (lower jaw } \\
\text { angle) }\end{array}$ & 3 & 1.8 & 0.23 & $-0.254(-13.7,11.64)$ \\
\hline & Total $\mathrm{CO} 2$ & Body shape (PC1) & 3 & 2.3 & 0.18 & $0.208(-6.15,8.47)$ \\
\hline & Total CO2 & $\begin{array}{l}\text { Ecomorph (lower jaw } \\
\text { angle) * size }\end{array}$ & 5 & 7.2 & 0.02 & $0.012(-9.42,11)$ \\
\hline \multirow[t]{4}{*}{13} & Saturated $02 \%$ & Intercept only & 2 & 0.0 & 0.60 & $-0.025(-1.24,1.19)$ \\
\hline & Saturated $02 \%$ & $\begin{array}{c}\text { Ecomorph (lower jaw } \\
\text { angle) }\end{array}$ & 3 & 2.4 & 0.182 & $2.132(-61.75,81.97)$ \\
\hline & Saturated $02 \%$ & Body shape (PC1) & 3 & 2.4 & 0.181 & $-0.726(-24.42,16.41)$ \\
\hline & Saturated $02 \%$ & $\begin{array}{l}\text { Ecomorph (lower jaw } \\
\text { angle) * size }\end{array}$ & 5 & 6.1 & 0.03 & $-0.492(-42.6,8.01)$ \\
\hline \multirow[t]{4}{*}{14} & Lactate & Body shape (PC1) & 3 & 0.0 & 0.50 & $-2.06 e-3(-0.6,0.59)$ \\
\hline & Lactate & Intercept only & 2 & 0.8 & 0.34 & $4.801(-1.41,20.57)$ \\
\hline & Lactate & $\begin{array}{c}\text { Ecomorph (lower jaw } \\
\text { angle) }\end{array}$ & 3 & 2.5 & 0.14 & $0.439(-31.45,37.02)$ \\
\hline & Lactate & $\begin{array}{l}\text { Ecomorph (lower jaw } \\
\text { angle) * size }\end{array}$ & 5 & 6.8 & 0.02 & $-0.132(-23.74,7.87)$ \\
\hline \multirow[t]{4}{*}{15} & $\begin{array}{l}\text { Packed Cell } \\
\text { Volume }\end{array}$ & Intercept only & 2 & 0.0 & 0.59 & $-4.72 \mathrm{e}-4(-0.24,0.24)$ \\
\hline & $\begin{array}{l}\text { Packed Cell } \\
\text { Volume }\end{array}$ & $\begin{array}{c}\text { Ecomorph (lower jaw } \\
\text { angle) }\end{array}$ & 3 & 2.0 & 0.22 & $-0.074(-8.82,8.18)$ \\
\hline & $\begin{array}{l}\text { Packed Cell } \\
\text { Volume }\end{array}$ & Body shape (PC1) & 3 & 2.4 & 0.18 & $-0.066(-5.31,4.56)$ \\
\hline & $\begin{array}{l}\text { Packed Cell } \\
\text { Volume }\end{array}$ & $\begin{array}{l}\text { Ecomorph (lower jaw } \\
\text { angle) * size }\end{array}$ & 5 & 7.5 & 0.01 & $-6.03 e-3(-7.43,6.56)$ \\
\hline \multirow[t]{4}{*}{16} & WBC & Intercept only & 2 & 0.0 & 0.47 & $0.005(-0.56,0.57)$ \\
\hline & WBC & Body shape (PC1) & 3 & 0.9 & 0.29 & $2.06(-4.61,18.7)$ \\
\hline & WBC & $\begin{array}{c}\text { Ecomorph (lower jaw } \\
\text { angle) }\end{array}$ & 3 & 1.4 & 0.23 & $-0.29(-17.9,15.51)$ \\
\hline & WBC & $\begin{array}{l}\text { Ecomorph (lower jaw } \\
\text { angle) * size }\end{array}$ & 5 & 7.3 & 0.01 & $-0.01(-16.25,13.55)$ \\
\hline
\end{tabular}


813 Table 4: Descriptive statistics for hematology parameters from four species of marine fish as compared to pinfish 814 (Lagodon rhomboides). Values indicate mean and standard deviations for blood parameters. Cameron (1970)

815 utilized heparinized capillaries and a scaled reading device to measure hematocrit and a cyanmethemoglobin method 816 to measure hemoglobin. Fazio et al. (2013) utilized a HeCo vet C blood cell counter (SEAC) to quantify hematocrit 817 and hemoglobin as well portable blood glucose (ACCU-Chek Active, Roche Diagnostics GmbH) and lactate

818 (Accusport, Boehringer) analyzers for the additional parameters.

Lagodon rhomboides-

\begin{tabular}{|c|c|c|c|c|c|c|}
\hline $\begin{array}{c}\text { Hematological } \\
\text { Parameters }\end{array}$ & $\begin{array}{c}1970 \\
(\mathrm{~N}=\text { not } \\
\text { reported })\end{array}$ & $\begin{array}{c}\text { Gobius niger } \\
\quad(\mathrm{N}=25)\end{array}$ & $\begin{array}{l}\text { Mugil } \\
\text { cephalus } \\
(\mathrm{N}=25)\end{array}$ & $\begin{array}{l}\text { Sparus } \\
\text { aurata } \\
(\mathrm{N}=25)\end{array}$ & $\begin{array}{l}\text { Dicentrarchus } \\
\text { labrax }(\mathrm{N}=25)\end{array}$ & $\begin{array}{l}\text { rhomboides- } \\
\text { This study } \\
(\mathrm{N}=37)\end{array}$ \\
\hline Hematocrit (\%) & 32.1 & $22.47 \pm 3.54$ & $\begin{array}{c}41.0 \pm \\
3.31\end{array}$ & $\begin{array}{c}53.33 \pm \\
4.42\end{array}$ & $49.29 \pm 6.17$ & $34.39 \pm 9.54$ \\
\hline $\begin{array}{l}\text { Hemoglobin } \\
(\mathrm{g} / \mathrm{dl})\end{array}$ & 7.6 & $5.67 \pm 0.89$ & $\begin{array}{c}11.07 \pm \\
1.05\end{array}$ & $\begin{array}{c}9.95 \pm \\
1.06\end{array}$ & $8.90 \pm 0.76$ & $11.7 \pm 3.24$ \\
\hline Glucose (mg/dl) & & $\begin{array}{c}168.90 \pm \\
35.39\end{array}$ & $\begin{array}{c}50.40 \pm \\
8.40\end{array}$ & $\begin{array}{c}192.8 \pm \\
47.00\end{array}$ & $246.50 \pm 30.93$ & $\begin{array}{c}169.7 \pm \\
101.43\end{array}$ \\
\hline Lactate $(\mathrm{mmol} / \mathrm{l})$ & & $3.38 \pm 0.62$ & $8.84 \pm 1.99$ & $\begin{array}{c}6.36 \pm \\
1.60\end{array}$ & $16.42 \pm 1.68$ & $9.93 \pm 4.56$ \\
\hline
\end{tabular}


Figure $\mathbf{1}$ (on next page)

Blood smear illustrating the different cell types (Wright-Giemsa stain, 1000X). 
Figure 2 (on next page)

(A) Placement of homologous landmarks (light circles) and sliding semi-landmarks (dark circles). (B) Linear and angular jaw measurements taken from each individual. 

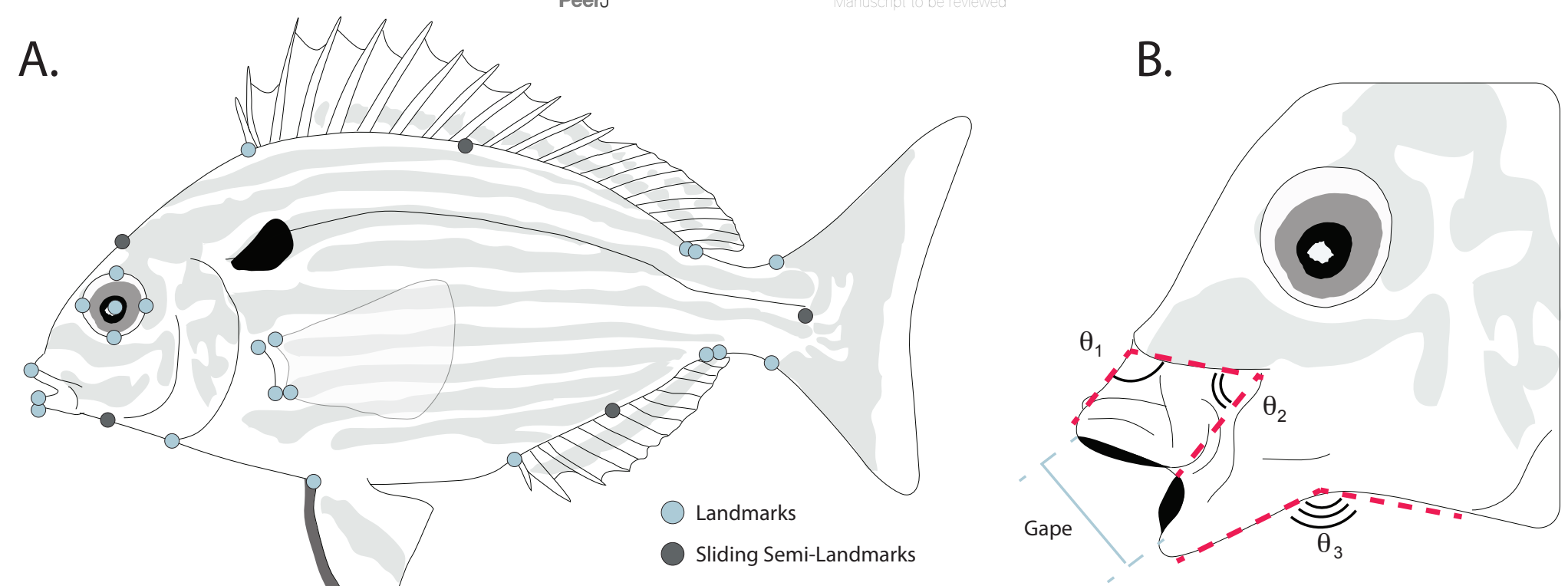


\section{Figure 3 (on next page)}

Visualizations of the first two principle component axes for changes in (A) body shape quantified by the geometric morphometric analyses; (B) jaw morphology; and (C) hematological data. Outlines correspond to the convex hull of the morphospace for female 
A.

PeerJ

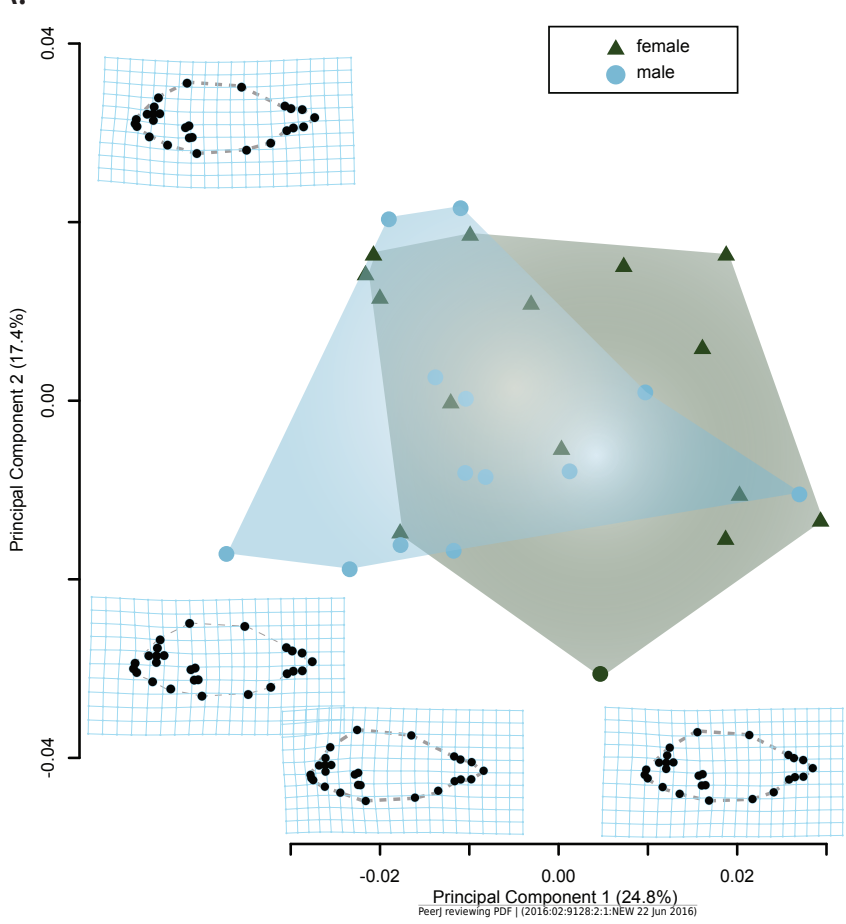

B.

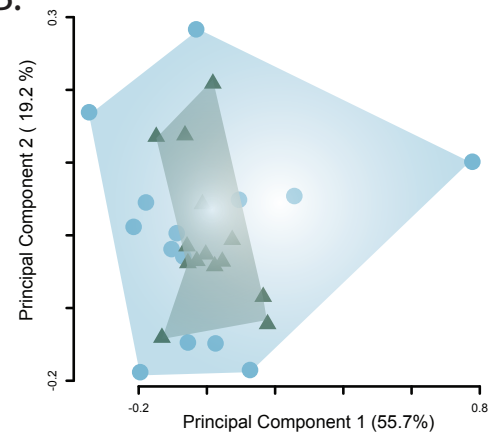

C.

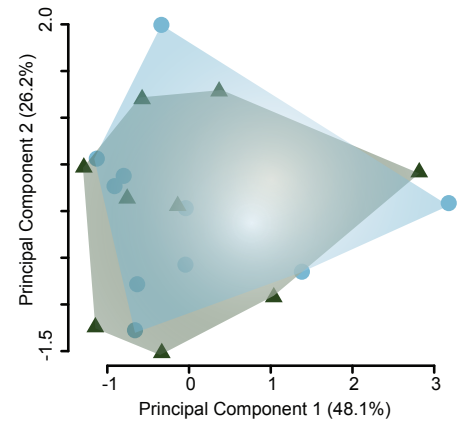




\section{Table $\mathbf{1}$ (on next page)}

Descriptive statistics of the blood gas and blood biochemical values collected. 
Table 1: Descriptive statistics of the blood gas and blood biochemical values collected. $\mathrm{N}=$ number of samples, $\mathrm{m}=$ males, $\mathrm{f}=\mathrm{females}, \mathrm{SD}=\mathrm{standard}$ deviation, $\mathrm{Min}=$ minimum value, $\mathrm{Max}=$ maximum value, $\mathrm{OOR}=$ number of samples outside of the recordable range of our instruments, $\mathrm{RI}=$ reference interval, $\mathrm{CI}=$ confidence interval. Reference Intervals were truncated with a lower bound of zero to maintain biological realism in non-negative blood parameters.

\begin{tabular}{|c|c|c|c|c|c|c|c|c|}
\hline Analyte & $\mathrm{N}(\mathrm{m} / \mathrm{f})$ & Mean, SD & $\begin{array}{c}\text { Quartile }(25 \%, \\
50 \%, 75 \%)\end{array}$ & Min (OOR) & $\begin{array}{l}\text { Max } \\
(\mathrm{OOR})\end{array}$ & $\begin{array}{c}\text { Reference } \\
\text { Interval }\end{array}$ & $\begin{array}{c}90 \% \mathrm{CI} \text { of } \\
\text { lower RI }\end{array}$ & $\begin{array}{c}90 \% \mathrm{CI} \text { of } \\
\text { upper RI }\end{array}$ \\
\hline $\mathrm{Na}(\mathrm{mmol} / \mathrm{L})$ & $37(14 / 17)$ & $168.84,7.04$ & $166,169,179$ & 156 & $>180(6)$ & $\begin{array}{l}154.0 \\
187.3\end{array}$ & $\begin{array}{l}149.4 \\
157.3\end{array}$ & $\begin{array}{l}183.3 \\
191.0\end{array}$ \\
\hline $\mathrm{K}(\mathrm{mmol} / \mathrm{L})$ & $31(14 / 12)$ & $4.7,1.4$ & $3.9,4.6,7.4$ & 3.1 & $>9.0(6)$ & $0.26,9.01$ & $0,1.28$ & $7.27,10.6$ \\
\hline $\begin{array}{l}\mathrm{iCa}(\mathrm{TC}) \\
(\mathrm{mmol} / \mathrm{L})\end{array}$ & $37(14 / 17)$ & $1.56,0.18$ & $\begin{array}{c}1.44,1.59 \\
1.66\end{array}$ & 1.23 & $>2.5(1)$ & $1.15,1.96$ & $1.04,1.23$ & $1.89,2.07$ \\
\hline $\begin{array}{l}\text { Glucose } \\
\text { (mg/dl) }\end{array}$ & $37(14 / 17)$ & $169.7,101.43$ & $84,155,217$ & 45 & 419 & $0,373.9$ & 0,0 & 307,444 \\
\hline Hct (\%) & $31(12 / 14)$ & $34.39,9.54$ & $30.5,34,37.5$ & 17 & 58 & $25.0,43.6$ & $22.2,27.6$ & $40.7,46.8$ \\
\hline $\mathrm{Hb}(\mathrm{g} / \mathrm{L})$ & $31(12 / 14)$ & $11.7,3.24$ & $\begin{array}{c}10.35,11.6 \\
12.75\end{array}$ & 5.8 & 19.7 & $8.59,14.8$ & $7.63,9.50$ & $13.9,15.9$ \\
\hline $\mathrm{pH}$ & $37(14 / 17)$ & $7,0.28$ & $\begin{array}{c}6.85,7.14 \\
7.32\end{array}$ & $<6.5(1)$ & 7.505 & $6.47,7.68$ & $6.30,6.62$ & $7.52,7.86$ \\
\hline Beecf & $36(14 / 16)$ & $-20.78,5.56$ & $\begin{array}{c}-29.25,-23.5,- \\
19.5\end{array}$ & $<-30(9)$ & -10 & $-37.5,-10.2$ & $-13.7,-5.1$ & $-40.0,-31.4$ \\
\hline $\begin{array}{c}\mathrm{HCO}^{3} \\
(\mathrm{mmol} / \mathrm{L})\end{array}$ & $36(14 / 16)$ & $7.52,3.07$ & $4.92,7.2,9.32$ & 3.3 & 13.8 & $0.52,13.4$ & $-0.97,2.36$ & $11.6,15.5$ \\
\hline $\mathrm{TCO}_{2}(\mathrm{mmHg})$ & $36(14 / 16)$ & $8.94,2.84$ & $6,8,11$ & $<5(6)$ & 14 & $1.97,14.0$ & $0.89,3.75$ & $12.1,16.0$ \\
\hline $\mathrm{sO}_{2} \%(\mathrm{mmHg})$ & $29(10 / 13)$ & $19.79,15.14$ & $6,16,32$ & 3 & 49 & $0,44.8$ & 0,0 & $34.2,56.5$ \\
\hline $\begin{array}{l}\text { Lactate } \\
(\mathrm{mmol} / \mathrm{L})\end{array}$ & $37(14 / 17)$ & $9.93,4.56$ & $6.4,9.9,13.9$ & 2 & 17.6 & $2.48,17.1$ & $0.63,4.29$ & $15.2,19.3$ \\
\hline PCV & $34(13 / 16)$ & $53.18,12.06$ & $45.25,50.5,60$ & 30 & 80 & $26.8,76.2$ & $20.4,32.7$ & $69.2,85.2$ \\
\hline
\end{tabular}




\section{Table 2 (on next page)}

Descriptive statistics of the manually analyzed hematology parameters collected. 
2 Table 2: Descriptive statistics of the manually analyzed hematology parameters collected. $N=$ number of samples, $m=$ males, $\mathrm{f}=\mathrm{females}, \mathrm{SD}=\mathrm{standard}$ deviation, 3 Min = minimum value, $\mathrm{Max}=$ maximum value, $\mathrm{RI}=$ reference interval, $\mathrm{CI}=$ confidence interval. Reference Intervals were truncated with a lower bound of zero to 4 maintain biological realism in non-negative blood parameters..

\begin{tabular}{|c|c|c|c|c|c|c|c|c|}
\hline Cell Type & $\mathrm{N}(\mathrm{m} / \mathrm{f})$ & Mean (SD) & Quartile $(25 \%, 50 \%, 75 \%)$ & Min & Max & $\begin{array}{c}\text { Reference } \\
\text { Interval }\end{array}$ & $\begin{array}{c}90 \% \text { CI of } \\
\text { lower RI }\end{array}$ & $\begin{array}{c}90 \% \text { CI of } \\
\text { upper RI }\end{array}$ \\
\hline Total WBC / ul & $30(14 / 13)$ & $\begin{array}{c}25,788 \\
(14,395.68)\end{array}$ & $16200,20000,32400$ & 6,800 & 73,200 & 0,54141 & 0,1647 & $\begin{array}{r}44684 \\
68230\end{array}$ \\
\hline Lymphocyte (\%) & $30(14 / 13)$ & $80.5(15.96)$ & $74.25,87,91$ & 39 & 96 & $52.1,123.0$ & $39.5,63.2$ & $113.6,135$ \\
\hline Neutrophil (\%) & $30(14 / 13)$ & $17.1(14.86)$ & $7,11,22.5$ & 2 & 54 & $0,44.0$ & 0,0 & $34.0,55.5$ \\
\hline Monocyte (\%) & $17(7 / 8)$ & $3.8(2.51)$ & $2,3,5$ & 0 & 11 & $0,8.72$ & $0,-5.78$ & $6.23,11.7$ \\
\hline
\end{tabular}




\section{Table 3(on next page)}

Results of GLM fitting to test predictive power of morphological data on hematological parameters. 
Table 3: Results of GLM fitting to test predictive power of morphological data on hematological parameters. Df= degrees of freedom, $\triangle \mathrm{AIC}=$ difference in AIC score between the model and the best-fitting model, $w i=\mathrm{AIC}$ weight, $\mathrm{df}=$ degrees of freedom, $\mathrm{WBC}=$ white blood cell count.

Set Response Variable Predictor Variable df $\triangle \mathrm{AICc} w_{i} \quad$ Model-Averaged

\begin{tabular}{|c|c|c|c|c|c|c|}
\hline & & & & & \multicolumn{2}{|c|}{ Coefficients $(95 \% \mathrm{CI})$} \\
\hline \multirow[t]{4}{*}{1} & Sodium & Intercept only & 2 & 0.0 & 0.43 & $-3.09 \mathrm{e}-4(-0.05,0.05)$ \\
\hline & Sodium & $\begin{array}{c}\text { Ecomorph (lower jaw } \\
\text { angle) }\end{array}$ & 3 & 0.8 & 0.31 & $0.09(-1.52,2.07)$ \\
\hline & Sodium & $\begin{array}{l}\text { Ecomorph (lower jaw } \\
\text { angle) * size }\end{array}$ & 5 & 5.5 & 0.24 & $0.115(-0.41,1.37)$ \\
\hline & Sodium & Body shape (PC1) & 3 & 10.6 & 0.02 & $-0.008(-1.55,0.92)$ \\
\hline \multirow[t]{4}{*}{2} & Potassium & Intercept only & 2 & 0.0 & 0.56 & $2.23 e-3(-0.46,0.47)$ \\
\hline & Potassium & $\begin{array}{c}\text { Ecomorph (lower jaw } \\
\text { angle) }\end{array}$ & 3 & 1.6 & 0.20 & $-0.476(-19.62,16.00)$ \\
\hline & Potassium & Body shape (PC1) & 3 & 2.4 & 0.09 & $-0.321(-10.67,6.95)$ \\
\hline & Potassium & $\begin{array}{l}\text { Ecomorph (lower jaw } \\
\text { angle) * size }\end{array}$ & 5 & 7.4 & 0.01 & $0.028(-13.11,17.26)$ \\
\hline \multirow[t]{4}{*}{3} & Calcium & Intercept only & 2 & 0.0 & 0.54 & $4.46 e-4(-0.13,0.13)$ \\
\hline & Calcium & Body shape (PC1) & 3 & 1.3 & 0.28 & $0.431(-1.49,4.56)$ \\
\hline & Calcium & $\begin{array}{c}\text { Ecomorph (lower jaw } \\
\text { angle) }\end{array}$ & 3 & 2.4 & 0.16 & $-0.011(-5.36,5.23)$ \\
\hline & Calcium & $\begin{array}{l}\text { Ecomorph (lower jaw } \\
\text { angle) * size }\end{array}$ & 5 & 7.8 & 0.01 & $-0.001(-4.45,4.21)$ \\
\hline \multirow[t]{4}{*}{4} & Glucose & Intercept only & 2 & 0.0 & 0.56 & $4.90 \mathrm{e}-4(-0.71,0.71)$ \\
\hline & Glucose & $\begin{array}{c}\text { Ecomorph (lower jaw } \\
\text { angle) }\end{array}$ & 3 & 1.5 & 0.26 & $-0.544(-25.11,21.19)$ \\
\hline & Glucose & Body shape (PC1) & 3 & 2.4 & 0.17 & $-0.075(-14.09,13.18)$ \\
\hline & Glucose & $\begin{array}{l}\text { Ecomorph (lower jaw } \\
\text { angle) * size }\end{array}$ & 5 & 7.0 & 0.01 & $0.01(-18.36,19.49)$ \\
\hline \multirow[t]{4}{*}{5} & Hematocrit & $\begin{array}{c}\text { Ecomorph (lower jaw } \\
\text { angle) }\end{array}$ & 3 & 0.0 & 0.38 & $0.046(-0.65,0.74)$ \\
\hline & Hematocrit & Intercept only & 2 & 0.3 & 0.32 & $-2.457(-33.26,21.99)$ \\
\hline & Hematocrit & Body shape (PC1) & 3 & 0.9 & 0.24 & $0.993(-2.09,10.38)$ \\
\hline & Hematocrit & $\begin{array}{l}\text { Ecomorph (lower jaw } \\
\text { angle) * size }\end{array}$ & 5 & 3.9 & 0.06 & $0.356(-3.73,16.92)$ \\
\hline \multirow[t]{4}{*}{6} & Hemoglobin & $\begin{array}{c}\text { Ecomorph (lower jaw } \\
\text { angle) }\end{array}$ & 3 & 0.0 & 0.36 & $0.044(-0.64,0.73)$ \\
\hline & Hemoglobin & Intercept only & 2 & 0.2 & 0.34 & $-2.335(-33.01,21.92)$ \\
\hline & Hemoglobin & Body shape (PC1) & 3 & 0.8 & 0.25 & $0.993(-2.14,10.32)$ \\
\hline & Hemoglobin & $\begin{array}{l}\text { Ecomorph (lower jaw } \\
\text { angle) * size }\end{array}$ & 5 & 3.9 & 0.05 & $0.339(-3.77,16.9)$ \\
\hline \multirow[t]{4}{*}{7} & $\mathrm{pH}$ & Intercept only & 2 & 0.0 & 0.47 & $2.33 e-4(-0.05,0.05)$ \\
\hline & $\mathrm{pH}$ & Body shape (PC1) & 3 & 0.8 & 0.31 & $-0.188(-1.54,0.36)$ \\
\hline & $\mathrm{pH}$ & $\begin{array}{c}\text { Ecomorph (lower jaw } \\
\text { angle) }\end{array}$ & 3 & 1.7 & 0.20 & $-0.012(-2.23,2.12)$ \\
\hline & $\mathrm{pH}$ & $\begin{array}{l}\text { Ecomorph (lower jaw } \\
\text { angle) * size }\end{array}$ & 5 & 6.6 & 0.02 & $7.72 \mathrm{e}-3(-0.89,1.79)$ \\
\hline \multirow[t]{4}{*}{8} & $\mathrm{PCO} 2$ & Intercept only & 2 & 0.0 & 0.55 & $7.49 \mathrm{e}-4(-0.38,0.38)$ \\
\hline & $\mathrm{PCO} 2$ & Body shape (PC1) & 3 & 1.7 & 0.24 & $0.795(-4.73,11.33)$ \\
\hline & $\mathrm{PCO} 2$ & $\begin{array}{c}\text { Ecomorph (lower jaw } \\
\text { angle) }\end{array}$ & 3 & 2.0 & 0.20 & $-0.145(-14.67,13.33)$ \\
\hline & $\mathrm{PCO} 2$ & $\begin{array}{l}\text { Ecomorph (lower jaw } \\
\text { angle) * size }\end{array}$ & 5 & 7.4 & 0.01 & $3.69 \mathrm{e}-3(-11.73,11.18)$ \\
\hline 9 & $\mathrm{PO} 2$ & Body shape (PC1) & 3 & 0.0 & 0.38 & $-6.51 \mathrm{e}-3(-0.75,0.74)$ \\
\hline
\end{tabular}




\begin{tabular}{|c|c|c|c|c|c|c|}
\hline & $\mathrm{PO} 2$ & Intercept only & 2 & 0.2 & 0.33 & $-4.14(-24.82,2.88)$ \\
\hline & $\mathrm{PO} 2$ & $\begin{array}{c}\text { Ecomorph (lower jaw } \\
\text { angle) }\end{array}$ & 3 & 0.7 & 0.27 & $0.906(-21.21,27.54)$ \\
\hline & $\mathrm{PO} 2$ & $\begin{array}{l}\text { Ecomorph (lower jaw } \\
\text { angle) * size }\end{array}$ & 5 & 6.1 & 0.02 & $-0.024(-21.08,18.33)$ \\
\hline \multirow[t]{4}{*}{10} & BEEcf & Intercept only & 2 & 0.0 & 0.55 & $4.45 e-4(-0.35,0.36)$ \\
\hline & BEEcf & $\begin{array}{c}\text { Ecomorph (lower jaw } \\
\text { angle) }\end{array}$ & 3 & 1.5 & 0.25 & $0.187(-11.15,12.52)$ \\
\hline & BEEcf & Body shape (PC1) & 3 & 2.3 & 0.18 & $-0.218(-8.12,5.62)$ \\
\hline & BEEcf & $\begin{array}{l}\text { Ecomorph (lower jaw } \\
\text { angle) * size }\end{array}$ & 5 & 7.0 & 0.02 & $0.012(-8.86,10.25)$ \\
\hline \multirow[t]{4}{*}{11} & Bicarbonate & Intercept only & 2 & 0.0 & 0.61 & $8.62 \mathrm{e}-4(-0.41,0.41)$ \\
\hline & Bicarbonate & $\begin{array}{c}\text { Ecomorph (lower jaw } \\
\text { angle) }\end{array}$ & 3 & 2.3 & 0.20 & $-0.178(-16.35,14.66)$ \\
\hline & Bicarbonate & Body shape (PC1) & 3 & 2.4 & 0.18 & $-0.013(-8.92,8.78)$ \\
\hline & Bicarbonate & $\begin{array}{l}\text { Ecomorph (lower jaw } \\
\text { angle) * size }\end{array}$ & 5 & 7.7 & 0.01 & $0.015(-11.3,13.54)$ \\
\hline \multirow[t]{4}{*}{12} & Total $\mathrm{CO} 2$ & Intercept only & 2 & 0.0 & 0.57 & $9.82 \mathrm{e}-4(-0.36,0.36)$ \\
\hline & Total CO2 & $\begin{array}{c}\text { Ecomorph (lower jaw } \\
\text { angle) }\end{array}$ & 3 & 1.8 & 0.23 & $-0.254(-13.7,11.64)$ \\
\hline & Total CO2 & Body shape (PC1) & 3 & 2.3 & 0.18 & $0.208(-6.15,8.47)$ \\
\hline & Total CO2 & $\begin{array}{l}\text { Ecomorph (lower jaw } \\
\text { angle) * size }\end{array}$ & 5 & 7.2 & 0.02 & $0.012(-9.42,11)$ \\
\hline \multirow[t]{4}{*}{13} & Saturated $02 \%$ & Intercept only & 2 & 0.0 & 0.60 & $-0.025(-1.24,1.19)$ \\
\hline & Saturated $02 \%$ & $\begin{array}{c}\text { Ecomorph (lower jaw } \\
\text { angle) }\end{array}$ & 3 & 2.4 & 0.182 & $2.132(-61.75,81.97)$ \\
\hline & Saturated $02 \%$ & Body shape (PC1) & 3 & 2.4 & 0.181 & $-0.726(-24.42,16.41)$ \\
\hline & Saturated $02 \%$ & $\begin{array}{l}\text { Ecomorph (lower jaw } \\
\text { angle) * size }\end{array}$ & 5 & 6.1 & 0.03 & $-0.492(-42.6,8.01)$ \\
\hline \multirow[t]{4}{*}{14} & Lactate & Body shape (PC1) & 3 & 0.0 & 0.50 & $-2.06 e-3(-0.6,0.59)$ \\
\hline & Lactate & Intercept only & 2 & 0.8 & 0.34 & $4.801(-1.41,20.57)$ \\
\hline & Lactate & $\begin{array}{c}\text { Ecomorph (lower jaw } \\
\text { angle) }\end{array}$ & 3 & 2.5 & 0.14 & $0.439(-31.45,37.02)$ \\
\hline & Lactate & $\begin{array}{l}\text { Ecomorph (lower jaw } \\
\text { angle) * size }\end{array}$ & 5 & 6.8 & 0.02 & $-0.132(-23.74,7.87)$ \\
\hline \multirow[t]{4}{*}{15} & $\begin{array}{l}\text { Packed Cell } \\
\text { Volume }\end{array}$ & Intercept only & 2 & 0.0 & 0.59 & $-4.72 \mathrm{e}-4(-0.24,0.24)$ \\
\hline & $\begin{array}{l}\text { Packed Cell } \\
\text { Volume }\end{array}$ & $\begin{array}{c}\text { Ecomorph (lower jaw } \\
\text { angle) }\end{array}$ & 3 & 2.0 & 0.22 & $-0.074(-8.82,8.18)$ \\
\hline & $\begin{array}{l}\text { Packed Cell } \\
\text { Volume }\end{array}$ & Body shape (PC1) & 3 & 2.4 & 0.18 & $-0.066(-5.31,4.56)$ \\
\hline & $\begin{array}{l}\text { Packed Cell } \\
\text { Volume }\end{array}$ & $\begin{array}{l}\text { Ecomorph (lower jaw } \\
\text { angle) * size }\end{array}$ & 5 & 7.5 & 0.01 & $-6.03 e-3(-7.43,6.56)$ \\
\hline \multirow[t]{4}{*}{16} & WBC & Intercept only & 2 & 0.0 & 0.47 & $0.005(-0.56,0.57)$ \\
\hline & WBC & Body shape (PC1) & 3 & 0.9 & 0.29 & $2.06(-4.61,18.7)$ \\
\hline & WBC & $\begin{array}{c}\text { Ecomorph (lower jaw } \\
\text { angle) }\end{array}$ & 3 & 1.4 & 0.23 & $-0.29(-17.9,15.51)$ \\
\hline & WBC & $\begin{array}{l}\text { Ecomorph (lower jaw } \\
\text { angle) * size }\end{array}$ & 5 & 7.3 & 0.01 & $-0.01(-16.25,13.55)$ \\
\hline
\end{tabular}




\section{Table 4 (on next page)}

Descriptive statistics for hematology parameters from four species of marine fish as compared to pinfish (Lagodon rhomboides).

Values indicate mean and standard deviations for blood parameters. Cameron (1970) utilized heparinized capillaries and a scaled reading device to measure hematocrit and a cyanmethemoglobin method to measure hemoglobin. Fazio et al. (2013) utilized a HeCo vet $\mathrm{C}$ blood cell counter (SEAC) to quantify hematocrit and hemoglobin as well portable blood glucose (ACCU-Chek Active, Roche Diagnostics GmbH) and lactate (Accusport, Boehringer) analyzers for the additional parameters. 
1 Table 4: Descriptive statistics for hematology parameters from four species of marine fish as compared to pinfish 2 (Lagodon rhomboides). Values indicate mean and standard deviations for blood parameters. Cameron (1970)

3 utilized heparinized capillaries and a scaled reading device to measure hematocrit and a cyanmethemoglobin method 4 to measure hemoglobin. Fazio (2013) utilized a HeCo vet $\mathrm{C}$ blood cell counter (SEAC) to quantify hematocrit and

5 hemoglobin as well portable blood glucose (ACCU-Chek Active, Roche Diagnostics GmbH) and lactate (Accusport,

6 Boehringer) analyzers for the additional parameters.

\begin{tabular}{|c|c|c|c|c|c|c|}
\hline $\begin{array}{c}\text { Hematological } \\
\text { Parameters }\end{array}$ & $\begin{array}{c}\text { Lagodon } \\
\text { rhomboides- } \\
1970 \\
\text { (N=not } \\
\text { reported) }\end{array}$ & $\begin{array}{c}\text { Gobius niger } \\
(\mathrm{N}=25)\end{array}$ & $\begin{array}{c}\text { Mugil } \\
\text { cephalus } \\
(\mathrm{N}=\mathbf{2 5}) \\
\end{array}$ & $\begin{array}{c}\text { Sparus } \\
\text { aurata } \\
(\mathrm{N}=25)\end{array}$ & $\begin{array}{l}\text { Dicentrarchus } \\
\text { labrax }(\mathrm{N}=25)\end{array}$ & $\begin{array}{l}\text { Lagodon } \\
\text { rhomboides- } \\
\text { This study } \\
(\mathrm{N}=37)\end{array}$ \\
\hline Hematocrit (\%) & 32.1 & $22.47 \pm 3.54$ & $\begin{array}{c}41.0 \pm \\
3.31\end{array}$ & $\begin{array}{c}53.33 \pm \\
4.42\end{array}$ & $49.29 \pm 6.17$ & $34.39 \pm 9.54$ \\
\hline $\begin{array}{l}\text { Hemoglobin } \\
(\mathrm{g} / \mathrm{dl})\end{array}$ & 7.6 & $5.67 \pm 0.89$ & $\begin{array}{c}11.07 \pm \\
1.05\end{array}$ & $\begin{array}{c}9.95 \pm \\
1.06\end{array}$ & $8.90 \pm 0.76$ & $11.7 \pm 3.24$ \\
\hline Glucose (mg/dl) & & $\begin{array}{c}168.90 \pm \\
35.39\end{array}$ & $\begin{array}{c}50.40 \pm \\
8.40\end{array}$ & $\begin{array}{c}192.8 \pm \\
47.00\end{array}$ & $246.50 \pm 30.93$ & $\begin{array}{c}169.7 \pm \\
101.43\end{array}$ \\
\hline Lactate $(\mathrm{mmol} / \mathrm{l})$ & & $3.38 \pm 0.62$ & $8.84 \pm 1.99$ & $\begin{array}{c}6.36 \pm \\
1.60\end{array}$ & $16.42 \pm 1.68$ & $9.93 \pm 4.56$ \\
\hline
\end{tabular}

